\title{
Aerosol direct radiative effect in the Po Valley region derived from AERONET measurements
}

\author{
M. Clerici and F. Mélin \\ European Commission - DG Joint Research Centre, Institute for Environment and Sustainability, Global Environment \\ Monitoring Unit, TP272, Ispra, 21020, Italy
}

Received: 24 September 2007 - Published in Atmos. Chem. Phys. Discuss.: 15 February 2008

Revised: 30 July 2008 - Accepted: 31 July 2008 - Published: 27 August 2008

\begin{abstract}
The aerosol direct radiative effect (ADRE) affecting the Po Valley and the adjacent North Adriatic Sea is studied using 10-year series of measurements collected at two AERONET sites located in the western part of the Valley (Ispra), and on a platform (AAOT) offshore Venice. This region is characterized by a high, mostly continental, aerosol load with comparable average aerosol optical thickness $\tau_{a}$ at both locations ( 0.21 at $500 \mathrm{~nm}$ ) and more absorbing aerosols at Ispra. A dynamic aerosol model accounting for the changes in scattering phase function with $\tau_{a}$ is used for radiative transfer calculations, together with boundary conditions representative of terrestrial and marine surfaces. A sensitivity analysis allows the construction of an error budget for the daily ADRE estimates, found to be of the order of $20 \%$ and mostly due to uncertainties on aerosol single scattering albedo and $\tau_{a}$. The daily radiative efficiencies, normalized by $\tau_{a}$ at $500 \mathrm{~nm}$, increase from December to June, from -17 to $-24 \mathrm{~W} \mathrm{~m}^{-2} \tau_{a}^{-1}$ at top-of-atmosphere (TOA) and -33 to $-72 \mathrm{~W} \mathrm{~m}^{-2} \tau_{a}^{-1}$ at surface for the Po Valley, and from -15 to -32 (TOA) and -35 to $-65 \mathrm{~W} \mathrm{~m}^{-2} \tau_{a}^{-1}$ (surface) for the AAOT site. The average of log-transformed ADRE for TOA, surface and atmosphere are $-5.2,-12.2$ and $+6.8 \mathrm{~W} \mathrm{~m}^{-2}$ for the Po Valley case, and $-6.5,-13.0$ and $+6.5 \mathrm{~W} \mathrm{~m}^{-2}$ for the AAOT site but these values can be much higher for individual days. Concurrent clear-sky days give indications on the regional atmospheric heating spatial gradients. Differences between the atmospheric ADRE at the two locations average $6.3 \mathrm{~W} \mathrm{~m}^{-2}$ with a gradient positive towards the inner valley in $65 \%$ of the cases. This study confirms the importance of duly considering the radiative impact of aerosols on the regional climate.
\end{abstract}

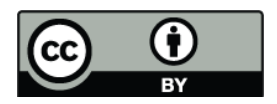

Correspondence to: $\mathrm{M}$. Clerici (marco.clerici@jrc.it)

\section{Introduction}

Aerosols have an impact on the radiative budget and hydrological cycle of the Earth through a variety of processes (Charlson et al., 1992; Ramanathan et al., 2001). A direct action is by the scattering and absorption of solar radiation, the latter in turn reducing cloud cover by heating the lower atmosphere (the semi-direct effect, Hansen et al., 1997). Moreover, by affecting cloud microphysical properties and lifetime, the aerosol particle distribution further affects the planetary albedo and precipitation patterns (Lohmann and $\mathrm{Fe}$ ichter, 2005; Rosenfeld, 2000). This overall impact is now widely recognized for global studies but the uncertainties associated with the aerosol effects remain higher than those associated with greenhouse gases (IPCC, 2001). A factor contributing to these uncertainties is the temporal and geographic variability of aerosols and their properties that partly explains the large diversity of published estimates (Yu et al., 2006). Particularly, the spatial gradients of the radiative effect of aerosols are much higher than those of greenhouse gases (Matsui and Pielke, 2006) and logically, several studies have focused on how aerosols may affect regional climates in areas of intense sources (e.g., Menon et al., 2002; Chung et al., 2002; Lau et al., 2006).

In Europe, the Po Valley (northern Italy) is a densely populated region, with intense rural and industrial activities, that stands out in regional maps of aerosol load (Chu et al., 2003; Barnaba and Gobbi, 2004) or emitted gases like $\mathrm{NO}_{2}$ (Beirle et al., 2004). Besides the concerns for air quality and health, studies of aerosols are needed for an accurate characterization of the radiative budget of the area. The present contribution is based on two 10-year time series of sun-photometer measurements that serve for radiative transfer computations and for the estimation of the aerosol direct radiative effect (ADRE). The two sites, separated by approximately $300 \mathrm{~km}$, are adequately situated at two ends of the Valley, and provide measurements covering diurnal to inter-annual time scales.

Published by Copernicus Publications on behalf of the European Geosciences Union. 


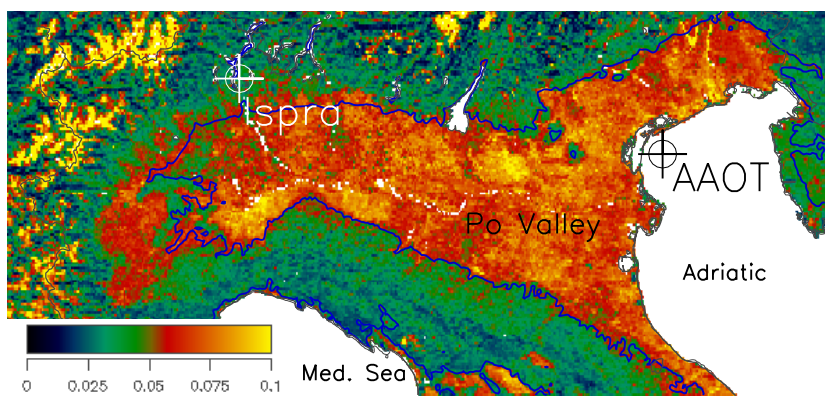

Fig. 1. Map of northern Italy, with the locations of the two AERONET sites of AAOT and Ispra. The background distribution is the 2003 annual average white-sky MODIS albedo (spectrally integrated for the $0.3-0.7 \mu \mathrm{m}$ domain). The blue line represents the 200-m elevation level, delineating the region of interest.

Interestingly, one site is located offshore in the coastal area of the northern Adriatic Sea and thus offers the opportunity to analyze the differences caused by different surface boundary conditions.

The main objective of the study is to quantify the aerosol direct radiative effect for the region at temporal scales from instantaneous to seasonal. The aerosol data are first described, and a comparative analysis of the direct radiative effect is performed for atmospheric and surface conditions characteristic of the two sites. Then, an assessment of the ADRE accuracy is performed taking into account different sources of error, related to the definition of the optical properties of the atmosphere-surface system and to methodological approximations. Finally, the daily to seasonal estimates of the aerosol direct radiative effect are presented.

\section{Data and methods}

\subsection{Description of the sites and data}

The study is based on measurements collected at two sites located at two ends of the Po Valley in northern Italy (Fig. 1). One site is in the precincts of the Joint Research Centre $\left(45^{\circ} 48^{\prime} \mathrm{N}, 08^{\circ} 37^{\prime} \mathrm{E}\right.$, elevation $\left.235 \mathrm{~m}\right)$, close to Ispra, a village $55 \mathrm{~km}$ northwest of Milan and $16 \mathrm{~km}$ west of Varese. This location is surrounded by villages, fields, forests and lakes. The second site is the Acqua Alta Oceanographic Tower (AAOT), located in the Adriatic Sea, $15 \mathrm{~km}$ off the Venice lagoon $\left(45^{\circ} 19^{\prime} \mathrm{N}, 12^{\circ} 30^{\prime} \mathrm{E}\right)$. The Po Valley has a flat topography surrounded by mountains (Alps and Apennines) and closed on the eastern side by the Adriatic Sea. Regional aerosol sources include large industrial, urban and rural emissions; air mass advection can also bring aerosols from the Mediterranean basin (with rare Saharan dust inputs; Rodríguez et al., 2007a) or from more northern European regions (e.g., Sogacheva et al., 2007). These conditions, together with low average levels of windiness (Rodríguez et al., 2007b), favor high loads of particles and pollutants (Van Dingenen et al., 2004; Beirle et al., 2004) and a relative homogeneity at the scale of the valley (Mélin and Zibordi, 2005). Information on chemical analyzes of Po Valley aerosols can be found in Matta et al. (2003) or Putaud et al. (2002, 2004).

Both measurement sites are part of the Aerosol Robotic Network (AERONET) (Holben et al., 1998). The instruments, CE-318 automated sun-photometers (CIMEL, Paris, France), have recorded radiometric data at the center wavelengths 440, 500, 675, 870, 940 and $1020 \mathrm{~nm}$ since August 1996 and July 1997 at the AAOT site and Ispra, respectively. Exceptions are the wavelength $500 \mathrm{~nm}$ not recorded at AAOT before July 1997 and at Ispra before February 2001, and an interruption in the Ispra time series between October 1998 and May 1999. The additional wavelengths at 412 and $555 \mathrm{~nm}$ are available after November 2001 at the AAOT site.

The direct solar irradiance measurements are used to derive the aerosol spectral optical thickness $\tau_{a}(\lambda)$ at the associated wavelength $\lambda$ through the Beer-Lambert-Bouguer law. The wavelength $940 \mathrm{~nm}$ is used only for the calculation of the amount of precipitable water vapor. The processing of the data is described by Holben et al. (1998) and Smirnov et al. (2000) (AERONET Version 2 direct Sun algorithm). Additionally, the Ångström exponent $\alpha$ has been computed by linear regression, as a function of wavelength, of the log-transformed $\tau_{a}$ between 440 and $870 \mathrm{~nm}$ ( 3 or 4 wavelengths). All the data are so-called Level 2 according to the cloud-screening and quality control from AERONET (Smirnov et al., 2000). An exception is the period at the AAOT before June 1999, that is considered Level 1.5 (the final step of quality assurance missing). The expected accuracy for the aerosol optical thickness is 0.015 (Eck et al., 1999). A daily value is computed as the average of all measurements recorded during the day if at least three measurements are available.

Additional information is used for a more comprehensive characterization of the aerosol properties at the two sites: the single scattering albedo $\omega_{a}$, the asymmetry factor $g_{a}$, the scattering phase function $\psi_{a}$ at $440,670,870$ and $1020 \mathrm{~nm}$, and the volume particle size distribution VSD. These estimates result from the AERONET Version 1 direct Sun and almucantar inversion algorithms (Dubovik and King, 2000) and are available for the periods June 1999 to December 2005 at the AAOT site, and July 1997 to November 2005 at Ispra. The inversions are based on the assumption of homogeneous spherical aerosols. In the case of aerosols dominated by fine particles (as for the considered sites, see below), the uncertainties for these inversions are estimated to be 0.03 for $\omega_{a}$, $15 \%$ to $25 \%$ for the VSD in the radius range 0.1 to $7 \mu \mathrm{m}$ and $25 \%$ to $100 \%$ for the tails of the size distribution (Dubovik et al., 2000).

The main optical properties of aerosols have been presented for these sites by Mélin and Zibordi (2005), and more completely for the AAOT site by Mélin et al. (2006). They are here briefly recalled and updated. The frequency 

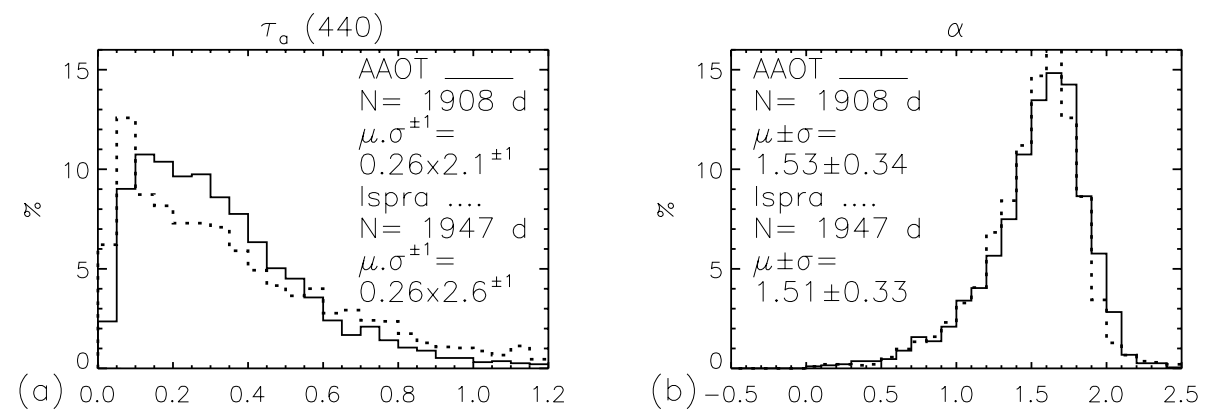

Fig. 2. Frequency distributions of the daily aerosol (a) optical thickness, $\tau_{a}$, at $440 \mathrm{~nm}$, and (b) Ångström exponent, $\alpha$. N, $\mu$, and $\sigma$ are the number of days, the overall mean, and the standard deviation of the distributions, respectively. For $\tau_{a}$, log-transformed statistics are presented (the arithmetic mean and standard deviation for $\tau_{a}(440)$ are $0.34 \pm 0.23$ and $0.37 \pm 0.29$ for AAOT and Ispra, respectively.)

distributions of the aerosol optical thickness $\tau_{a}$ at $440 \mathrm{~nm}$ (selected because this wavelength is available for the entire measurement record at both sites) and the Ångström exponent $\alpha$ are shown on Fig. 2, and a synthesis of the main optical properties is given in Table 1. The frequency distribution of the aerosol optical thickness is better approximated by a log-normal distribution than by a normal law, as proposed by O'Neill et al. (2000) and confirmed by Fig. 2 and by values of skewness and kurtosis, and thus log-transformed statistics are reported for $\tau_{a}$. On the basis of $N_{d}=1908$ daily records at the AAOT site, $\tau_{a}$ averages 0.264 at $440 \mathrm{~nm}(0.221$ at $500 \mathrm{~nm}$ with $N_{d}=1840$ daily records). For Ispra, these averages are 0.257 for $\tau_{a}(440)\left(N_{d}=1947\right)$ and 0.206 for $\tau_{a}(500)$ $\left(N_{d}=1303\right)$. The average Ångström exponent is also found similar at both sites, $1.53 \pm 0.34$ and $1.51 \pm 0.33$ at AAOT and Ispra, respectively. The relatively high values of $\alpha$ underline the predominance of continental aerosols, in line with the sources defining the aerosol regime in the Po Valley. These aerosol optical characteristics also resemble those of sites located in a urban/industrial environment (Holben et al., 2001; Dubovik et al., 2002).

The statistical basis available for the inherent optical properties is much smaller (Table 1), with a number of data records at the AAOT site and Ispra, respectively amounting to 2627 and 2253 for $g_{a}, \psi_{a}$ and VSD, and 797 and 727 for $\omega_{a}$ (these lower numbers are explained by the fact that the inversion algorithm does not return values for $\omega_{a}$ in cases of low value of $\tau_{a}$ ). A similar spectral dependency can be noticed for both sites, with $\omega_{a}$ decreasing with wavelength, as mostly observed for aerosols other than dust (e.g., Dubovik et al., 2002), and $g_{a}$ also decreasing with wavelength, consistent with a decrease in the scattering effective particle size (Hansen and Travis, 1974). The aerosols associated with the location of AAOT appear less absorbing on average; this might be due to a location farther from the main pollution sources and to a background marine component. These properties, in terms of amplitude and spectral dependence, are well in line with results published for other continental sites, even if the local sources might have dif-
Table 1. Overall statistics (average and standard deviation) for the aerosol optical thickness $\tau_{a}$ (log-transformed statistics), the Ångström exponent $\alpha$, the single scattering albedo $\omega_{a}$ and the asymmetry factor $g_{a}$. Wavelengths are indicated in nm. For $\tau_{a}$ and $\alpha$, the statistics are computed with the daily averages of the entire time series (see also Fig. 2); $N_{d}$ is the number of days, with the value in brackets given for $\tau_{a}(500)$. The statistics for $\omega_{a}$ and $g_{a}$ are computed over all $\mathrm{N}$ individual records.

\begin{tabular}{rrr}
\hline Site & AAOT & Ispra \\
\hline$\tau_{a}$ & $N_{d}=1908(1840)$ & $N_{d}=1947(1303)$ \\
440 & $0.264 \times 2.11^{ \pm} 1$ & $0.257 \times 2.55^{ \pm} 1$ \\
500 & $0.221 \times 2.15^{ \pm} 1$ & $0.206 \times 2.61^{ \pm} 1$ \\
675 & $0.141 \times 2.21^{ \pm} 1$ & $0.137 \times 2.66^{ \pm} 1$ \\
870 & $0.095 \times 2.22^{ \pm} 1$ & $0.094 \times 2.60^{ \pm} 1$ \\
$\alpha$ & $1.53 \pm 0.34$ & $1.51 \pm 0.33$ \\
$\omega_{a}$ & $N=797$ & $N=727$ \\
441 & $0.956 \pm 0.017$ & $0.928 \pm 0.032$ \\
673 & $0.942 \pm 0.025$ & $0.923 \pm 0.035$ \\
873 & $0.918 \pm 0.039$ & $0.908 \pm 0.044$ \\
1022 & $0.906 \pm 0.047$ & $0.898 \pm 0.051$ \\
$g a$ & $N=2627$ & $N=2253$ \\
441 & $0.691 \pm 0.032$ & $0.691 \pm 0.046$ \\
673 & $0.626 \pm 0.049$ & $0.606 \pm 0.055$ \\
873 & $0.595 \pm 0.050$ & $0.564 \pm 0.053$ \\
1022 & $0.579 \pm 0.053$ & $0.548 \pm 0.053$ \\
\hline
\end{tabular}

ferent charactistics. For instance, the average spectra of $\omega_{a}$ and $g_{a}$ appear close to those reported at Greenbelt, Maryland, US, and Créteil-Paris, France (Dubovik et al. 2002, at these 2 sites $\omega_{a}$ decreases from 0.98 to 0.95 and from 0.94 to 0.91 , respectively), or at Lecce, southeastern Italy (Perrone et al. 2005; 2 modes of the frequency distribution of $\omega_{a}(440)$ are there distinguished, centered at 0.94 and 0.974$)$. It is however acknowledged that much lower values of $\omega_{a}$ can be found, particularly close to large cities, as reported for example in summer for the Marseille or Paris urban areas (respectively, $\omega_{a}(550)$ of $0.85 \pm 0.05$, Mallet et al. 2003, 

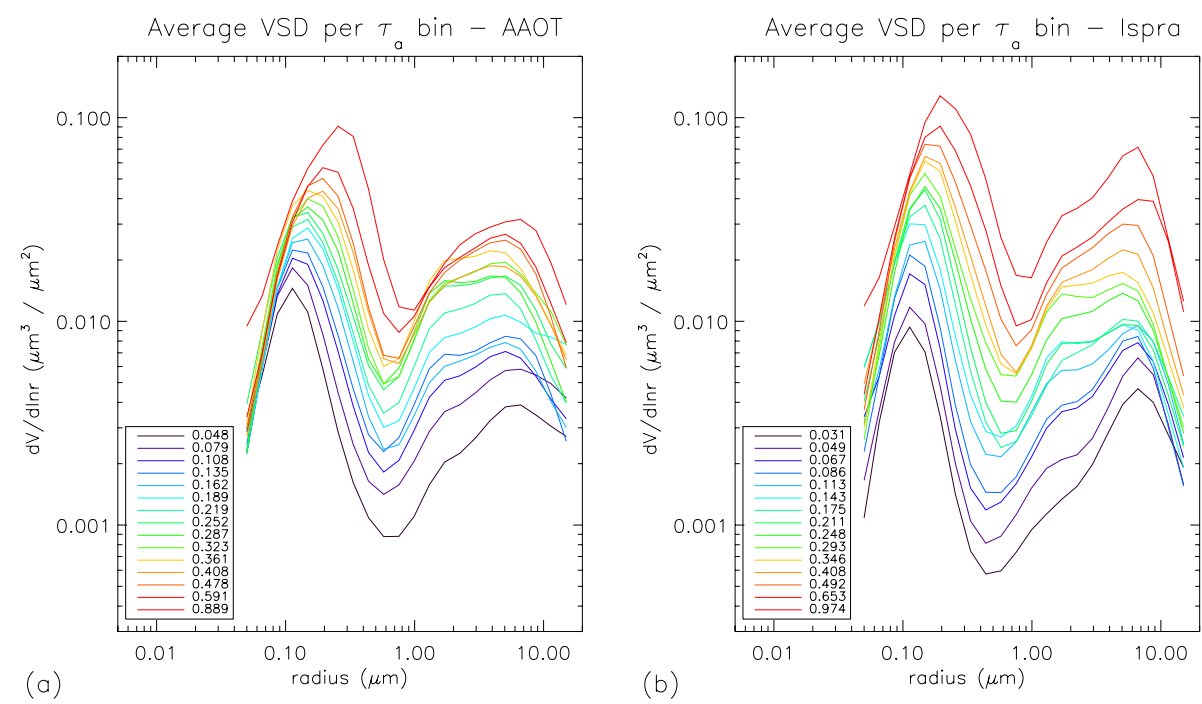

Fig. 3. Aerosol volume size distribution VSD averaged by bin of $\tau_{a}(500)$, for the AAOT (a) and Ispra (b) sites.

and $\omega_{a}(550)$ of $0.85-0.92$, Chazette et al. 2005), or as annual mean for Valencia, Spain $\left(\omega_{a}\right.$ of $0.90 \pm 0.05$, Estellés et al. 2007).

The similarity between the optical properties found at the two locations also confirms the results presented by Mélin and Zibordi (2005). That study also showed a large degree of temporal correlation between the two time series at various time scales, from daily to monthly. Conversely, the mean diurnal cycle was found to be quite different. The diurnal variability exhibited at the Ispra site is similar to that documented for other sites influenced by urban/industrial centers (Smirnov et al., 2002), with an increase of $\tau_{a}$ amounting to $\sim 10 \%$ on average between the mid-to-end morning and the end of the afternoon. Conversely, at the AAOT site the aerosol load is found to decrease from the early morning to the afternoon by an amplitude of $20 \%$ (annual average). The impact of this diurnal variability will be further addressed below in terms of aerosol radiative effect.

\subsection{Definition of the aerosol model for each site}

In a previous study (Mélin et al., 2006) and similarly to the work of Remer and Kaufman (1998), a relationship between aerosol optical properties and the particle volume size distribution has been illustrated for the AAOT site, and is now summarized and extended to the measurements collected at Ispra. Figure 3 represents the VSD averaged per interval of increasing $\tau_{a}$ at $500 \mathrm{~nm}$, with 15 intervals of equal sample size for each data set. Three modes are apparent for the VSD, whose modal radius $r_{v}$ can be computed assuming a combination of log-normal distributions. The positions of the modes associated with large particles are rather constant, 1.3 and $6.0 \mu \mathrm{m}$ for both data sets (average over all bins). Conversely, the modal radius of the small particles (accumulation mode) increases with the aerosol load, from 0.13 to $0.23 \mu \mathrm{m}$ at the AAOT site, and from 0.12 to $0.22 \mu \mathrm{m}$ at the Ispra site. This shift is associated with the growth of the small particles with humidity and is in line with the relationships found between precipitable water vapor and the amplitude and spectral shape of $\tau_{a}(\lambda)$ (see Mélin et al., 2006, for the AAOT site).

The aerosol scattering phase function $\psi_{a}$ also displays an angular dependence as the aerosol load increases (Fig. 4). Thus for both sites, the peaks of forward and backward scattering decreases for large $\tau_{a}$. The asymmetry factor $g_{a}$ reflects this trend, increasing slightly with $\tau_{a}$ (for instance, the bin-averaged $g_{a}$ at $440 \mathrm{~nm}$ approximately increases from 0.65 to 0.73 at both sites). The change in size distribution and water content is also translated in terms of single scattering albedo that tends to increase with $\tau_{a}$. As indicated in the previous sub-section, valid values for $\omega_{a}$ from the inversion process are obtained only for the high range of aerosol loads; in practice, $\omega_{a}$ statistics are available for the last five bins, corresponding to $\tau_{a}(500)$ above approximately 0.3 . Over this interval, the bin-averaged $\omega_{a}$ at $440 \mathrm{~nm}$ increases from 0.95 to 0.96 at the AAOT site, and from 0.92 to 0.95 at Ispra.

The clear relationship between $\tau_{a}$ and the aerosol physical (VSD) and inherent optical properties $\left(\psi_{a}\right)$ allows the definition of an aerosol model for each site, whose optical properties evolve dynamically with $\tau_{a}$ and are used for performing radiative transfer (RT) simulations, as described in Sect. 2.4. This has the advantage of accounting for the dependence on the size distribution of the radiative effect (Kiehl and Briegleb, 1993). Considering a statistical basis restricted to the high range of $\tau_{a}$, the spectrum of single scattering albedo is kept constant (values given in Table 1). From the four wavelengths available for $\psi_{a}$ and $\omega_{a}$, the spectrum of these optical properties is determined by extrapolation in the 

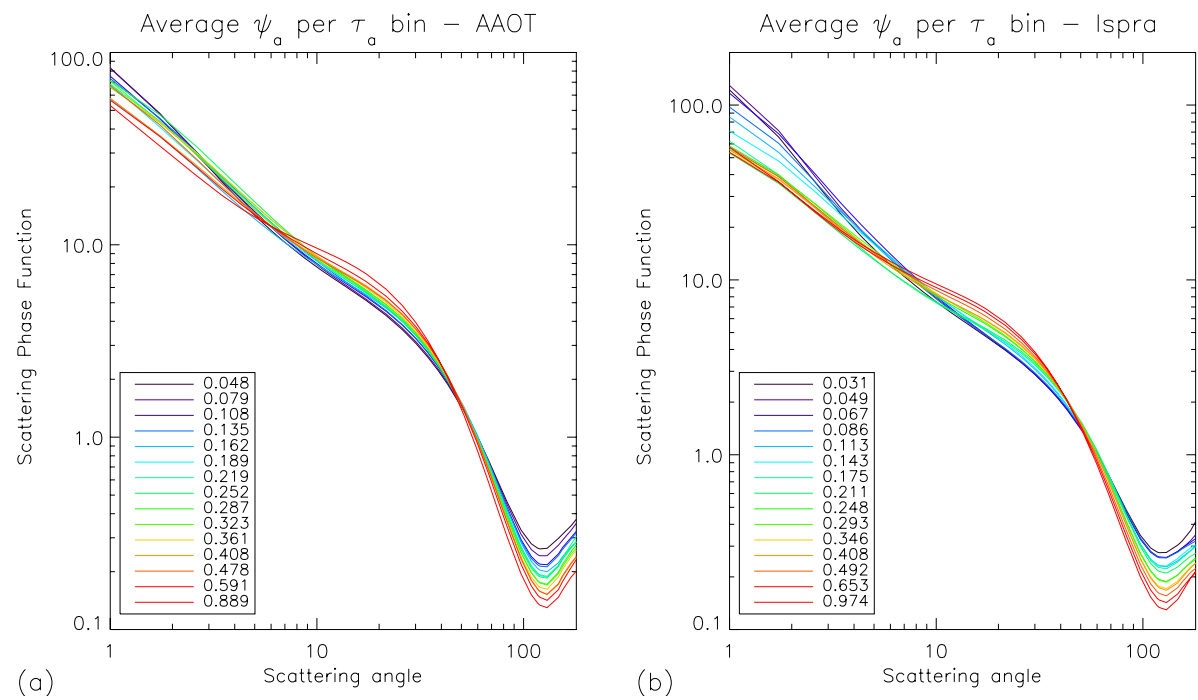

Fig. 4. Aerosol scattering phase function averaged by bin of $\tau_{a}(500)$, for the AAOT (a) and Ispra (b) sites.

range 0.25 to $2 \mu \mathrm{m}$. The uncertainties resulting from the extrapolation of the optical properties in the interval from 1 to $2 \mu \mathrm{m}$ can be considered as relatively small for these types of aerosols (Haywood and Shine, 1995; Russel et al., 1999; Redemann et al., 2000).

\subsection{Surface albedo}

The radiative transfer simulations require the definition of the surface boundary conditions. Over marine surfaces, the boundary condition is represented by a bidirectional reflectance distribution function (BRDF) for water (see Mayer and Kylling, 2005), mainly depending on wind speed according to the wave slope distribution of Cox and Munk (1956).

Over land, the values of the albedo $\rho$ are defined using the albedo product (collection 4) derived from the Moderate Resolution Imaging Spectroradiometer (MODIS, Salomonson et al., 1989) on board the Terra platform. This product is distributed as global maps (1-min spatial resolution) representing sixteen-day averages of the so-called black-sky and white-sky albedos for wavelengths centered at 0.47, 0.55, $0.67,0.86,1.24,1.64$, and $2.1 \mu \mathrm{m}$ (Schaaf et al., 2002; Moody et al., 2005). The black-sky albedo corresponds to the directional hemispherical reflectance computed at solar noon, and the white-sky albedo to the bi-hemispherical reflectance in conditions of isotropic illumination. The first validation analyses state an absolute accuracy mostly within \pm 0.02 for the integrated shortwave albedo (Lucht et al., 2000; Jin et al., 2003). This satellite data set is not available for the entire AERONET record, and the albedo annual cycle is here defined by considering the year 2003 as representative.

Figure 1 displays the 2003 annual average albedo (whitesky product) spectrally integrated for the visible domain
$(0.3-0.7 \mu \mathrm{m})$. The Po Valley is easily distinguished by white-sky albedo values higher than approximately 0.05 and elevations lower than $200 \mathrm{~m}$, the two thresholds matching remarkably well (the blue line on Fig. 1 thus encompasses the region of interest). This region is classified as cropland by the MODIS International Geosphere Biosphere Program ecosystem classification (Friedl et al., 2002), to which should be added the influence of large cities. The area in the immediate vicinity of Ispra is more rural and forested, with lower values of albedo. In order to analyze the aerosol radiative effect for the region, the albedo spectra averaged over a small area around Ispra (approximately $15 \mathrm{~km}$ ) and over the whole Po Valley, defined by elevations lower than $200 \mathrm{~m}$, are considered, and are shown on Fig. 5 as seasonal averages. Whitesky and black-sky albedos are close, particularly for the spectral domain below $0.9 \mu \mathrm{m}$ which is of primary interest for calculations of the aerosol radiative effect. The annual average white-sky albedo spectrally integrated in the domain $0.3-0.7 \mu \mathrm{m}$ is 0.036 and 0.067 around Ispra and for the Valley, respectively. For the interval $0.7-5 \mu \mathrm{m}$, it is 0.200 and 0.250 , respectively.

For the purpose of our study, the albedo used for the RT calculations is taken as the average of the noon white-sky and black-sky albedos weighted by the actual ratio of diffuse and direct irradiance. This takes into account the effect of the aerosol load on the geometry of the radiance field. The variations during the day with respect to the values at noon of the two albedo components are ignored, but the moderate dependence on the solar zenith angle should introduce small errors on the radiative effect, particularly for daily or monthly averages (Yu et al., 2004). Radiative transfer calculations are performed with the two types of surfaces and associated albedo values (Ispra and Po Valley). Differences between the results obtained by these two sets of calculations can be 

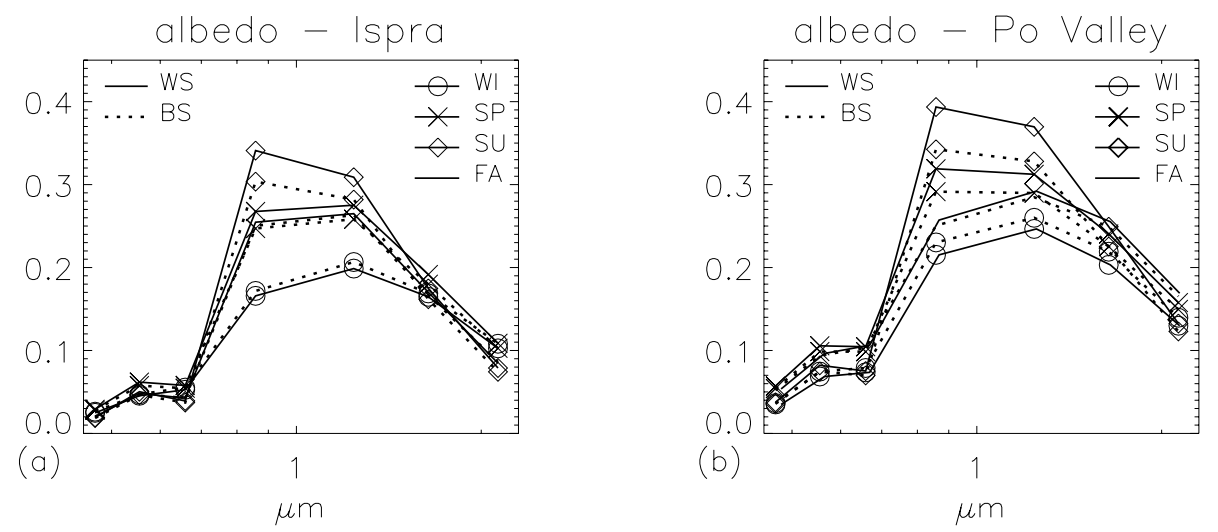

Fig. 5. Seasonal means of MODIS albedo spectrum averaged for the Ispra area (a) and the Po Valley region (b), as limited by the $200-\mathrm{m}$ elevation line. WS and BS stand for white-sky and black-sky, respectively. WI, SP, SU, and FA stand for the winter, spring, summer and fall seasons.

considered to assess the dependence on the albedo values as well as their associated uncertainties, including the intrinsic uncertainty of the product, the residual dependence on the solar zenith angle, or the possible impact of the inter-annual variability of the regional albedo.

For the sake of completeness, an albedo spectrum of uniformly snow-covered surfaces from the ASTER Spectral Library (Medium Granular Snow) is considered to assess the impact on ADRE of highly reflecting surfaces. These conditions are extreme for the Po Valley, where snow events are unfrequent (for instance at Ispra, in the pre-alpine part of the Valley, snow falls occurred just a few days per year in the last decade), and the properties of the ground at the scale of tens of kilometer are usually different from these snow simulations, because of heterogeneity of the snow cover remaining after snow fall. Snow cases are not specfically included into the time series presented in Sect. 4.

\subsection{Radiative transfer calculations}

The radiative budget with and without aerosols is determined using the libRadtran package (see Mayer and Kylling, 2005, for a complete overview) and applying the DISORT2 code for the radiative transfer computations (Stamnes et al., 1998). The solar irradiance spectrum is from Kurucz (1992) with a spectral resolution of $0.1 \mathrm{~nm}$. The standard US 1976 atmospheric profile (Anderson et al., 1986) is assumed for gas absorption and scattering, modelled over 50 plane parallel layers ranging from the surface up to $120 \mathrm{~km}$; the use of a different profile will impact the aerosol radiative effect within a few percent (Boucher and Tanré, 2000; Bellouin et al., 2003). The SBDART k-correlated parametrization is used for gas absorption in the near-infrared (Ricchiazzi et al., 1998). The aerosol load is homogeneously distributed in the lower troposphere, up to $3 \mathrm{~km}$, and the optical properties are represented by the single scattering albedo and the Legendre expansion of the scattering phase function. The importance of a proper representation of the aerosol scattering phase function in determining the radiative effects has been recognized in previous studies (e.g., Boucher, 1998a), so that a high number of coefficients (1000) of the Legendre expansion is selected to guarantee the accuracy of the phase function representation.

For the AAOT site, a BRDF for water surfaces is selected (Mayer and Kylling, 2005), with a wind speed of $2 \mathrm{~m} \mathrm{~s}^{-1}$ well representative of the average local meteorological conditions. Previous analyses, performed with a coupled wateratmosphere code, demonstrated that changes in the water content and its bio-optical properties do not result in significant changes in the radiative effect. An increase of the background chlorophyll $a$ concentration from 0.05 to $1.0 \mathrm{mg} \mathrm{m}^{-3}$ affects the ADRE by only $0.6 \%$ and $0.3 \%$ at the top-ofatmosphere and surface, respectively (Mélin et al., 2006). For terrestrial surfaces, a lambertian surface with albedo ranging from 0.02 to 0.5 (12 values) is assumed for calculations performed with the Ispra aerosol model. An additional configuration is considered by combining this aerosol model with the water BRDF, in order to separate the effect of the aerosol and surface properties on the radiative fluxes (see Sect. 3.1).

In practice, radiative transfer computations are performed with the aerosol models associated with each $\tau_{a}$ bin (Sect. 2.2), for every wavelength $\lambda$ and solar zenith angle $\theta_{0}$ in the range $20^{\circ}$ (lowest value at this latitude) to $85^{\circ}$ (by steps of $5^{\circ}$ ), and for the range of albedo values. The results are stored into a look-up table (LUT) for following analysis and representation of the results. As recalled previously, the Po Valley is characterized by a relative homogeneity of the aerosol properties and variability (see Sect. 2.1 and Mélin and Zibordi, 2005). Thus, in the standard RT calculations, the aerosol characteristics at Ispra are taken as representative of at least the inner Valley and are used for radiative simulations over land, whereas the aerosol characteristics associated with AAOT are used for calculations over the Adriatic 

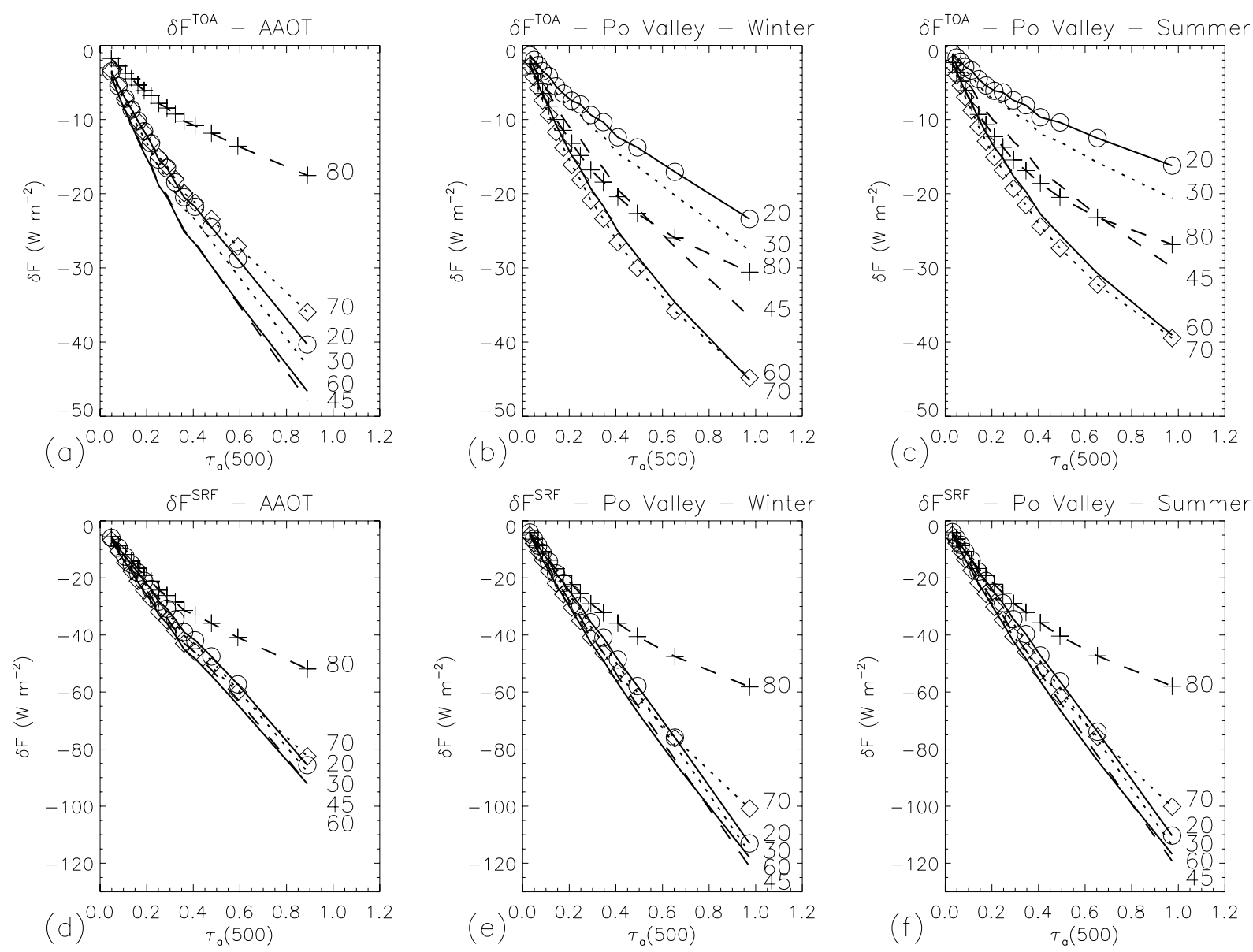

Fig. 6. Top-of-atmosphere (a), (b), (c) and surface (d), (e), (f) instantaneous aerosol direct radiative effect $\delta F$ as a function of $\tau_{a}$ for the AAOT site (a), (d), and the Po Valley in winter (b), (e) and summer (c), (f). The numbers associated with each curve is the solar zenith angle.

Sea. For sensitivity analyses, a reference case is defined by selecting the bins whose average $\tau_{a}$ is close to the overall average, $\tau_{a}=0.211$ for Ispra (8th bin), and $\tau_{a}=0.219$ for AAOT (7th bin).

First, the instantaneous radiative effect (spectrally resolved or integrated) associated with one $\tau_{a}$ bin is derived directly from the LUT for the top-of-atmosphere (TOA) as $\delta F^{\mathrm{TOA}}\left(\tau_{a}\right)$, expressed by the difference of the diffuse upward irradiance with and without aerosol, and for the surface, as $\delta F^{\mathrm{SRF}}\left(\tau_{a}\right)$ obtained by subtracting the total downward irradiance in presence of aerosol from that computed for an aerosol free atmosphere. For given $\tau_{a}$ and $\theta_{0}, \delta F$ is obtained from the LUT by bilinear interpolation. For terrestrial surfaces, the albedo spectrum typical of each season (Fig. 5) is selected, with values for a specific wavelength $\lambda$ obtained by interpolation between the MODIS channels. Subsequently $\delta F$ can be integrated in time at daily to seasonal scales to analyze the time series of the clear-sky aerosol direct radiative effect.

\section{Comparative analysis and uncertainties}

\subsection{Comparative analysis}

This section describes the characteristics of the aerosol direct radiative effect (ADRE) for sites representative of the Po Valley and the adjacent sea, particularly its variations with the aerosol optical thickness $\tau_{a}$, the aerosol model, the surface albedo (including land and sea), and the solar zenith angle $\theta_{0}$. Unless stated otherwise, the results are for RT calculations performed with the AAOT aerosol model and a water surface and with the Ispra aerosol model and the Po Valley typical albedo.

\subsubsection{Instantaneous aerosol direct radiative effect}

The instantaneous radiative effect at the surface, $\delta F^{\mathrm{SRF}}$ and at the top-of-atmosphere, $\delta F^{\mathrm{TOA}}$, computed for every solar zenith angle $\theta_{0}$ and every bin of the aerosol models (dependent on $\tau_{a}$ ), are presented on Fig. 6 . For the sake of clarity, only a subset of the $\theta_{0}$ values is displayed (thus the angle for which the radiative effect is maximum, noted $\theta_{0}^{\max }$, might not be represented). The results for the case of the Po Valley 

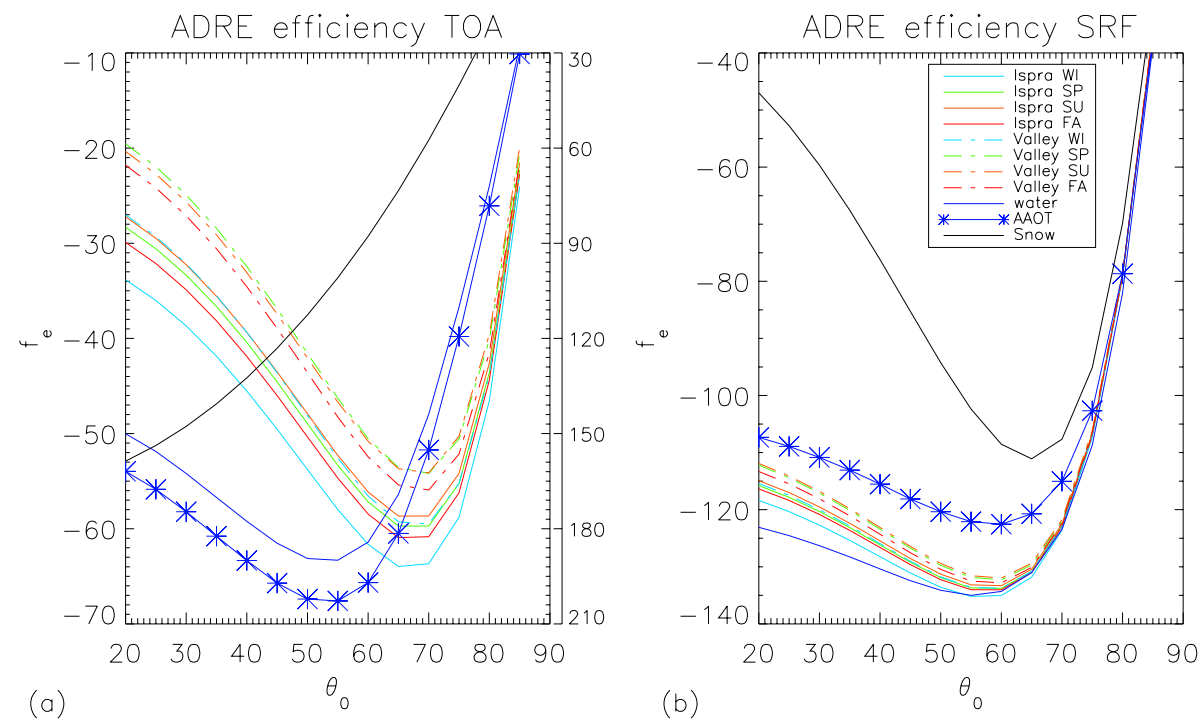

Fig. 7. Aerosol direct radiative effect efficiencies at TOA (a) and surface (b). The blue line represents $f_{e}$ computed over a water surface with the Ispra aerosol model. The blue line with asterisks is the AAOT reference case (AAOT aerosols and water surface). The other curves correspond to the Ispra aerosol model with typical albedos around Ispra and for the whole Po Valley (dashed lines) for the four seasons.

are shown for winter and summer albedos. At the surface, the dependence of $\delta F^{\mathrm{SRF}}$ on $\tau_{a}$ is close to linearity except for high solar zenith angles, whereas at TOA, this relationship departs from linearity for moderate $\tau_{a}$. The curves for $\theta_{0}$ equal to $80^{\circ}$ should be viewed with caution considering the plane-parallel assumptions of the RT calculations.

The relationship between $\delta F^{\mathrm{SRF}}$ and $\theta_{0}$ is very similar for the different terrestrial albedos and comparable for the water surface, even though the amplitude for a given $\tau_{a}$ is lower in that case (Fig. 6d-f). For the reference $\tau_{a}(500)$ (approximately 0.21 ) and for $\theta_{0}$ below $65^{\circ}, \delta F^{\mathrm{SRF}}$ is close to $-26 \mathrm{~W} \mathrm{~m}^{-2}$ for the marine case and $-28 \mathrm{~W} \mathrm{~m}^{-2}$ for the Po Valley for the four seasons. For the bin of highest $\tau_{a}(500)$ (0.97), the maximum value of $\delta F^{\mathrm{SRF}}$ for the Po Valley is between -121 and $-119 \mathrm{~W} \mathrm{~m}^{-2}$ for the four seasons, whereas it is $-93 \mathrm{~W} \mathrm{~m}^{-2}$ for the marine case (for $\tau_{a}(500)$ equal to 0.89 ).

Conversely, the relationship between $\delta F^{\mathrm{TOA}}$ and $\theta_{0}$ shows variations of amplitudes between seasons for the terrestrial case and a different angular dependence for the marine case. For instance for the reference $\tau_{a}(500)$ and $\theta_{0}$ of $20^{\circ}, \delta F^{\mathrm{TOA}}$ is between -5.8 and $-7.5 \mathrm{~W} \mathrm{~m}^{-2}$ for terrestrial surfaces over the four seasons, and $-13.2 \mathrm{~W} \mathrm{~m}^{-2}$ for the marine case (a factor of two higher). For $\theta_{0}$ equal to $60^{\circ}$, these numbers are from -13.6 to $-14.9 \mathrm{~W} \mathrm{~m}^{-2}$ and $-16.3 \mathrm{~W} \mathrm{~m}^{-2}$, respectively.

\subsubsection{Aerosol direct radiative effect efficiencies}

The instantaneous radiative efficiencies at TOA and surface are derived as the slope of the linear regression between $\delta F$ and $\tau_{a}(500)$. Considering the non linearities noticed on Fig. 6 for high aerosol loads, the range of $\tau_{a}(500)$ values used for the regression is restricted to the first 13 bins, i.e., for $\tau_{a}(500)$ approximately lower than 0.5 , that is the average value multiplied by the geometric standard deviation (see Table 1). The efficiencies computed on this interval are higher than those obtained over the whole range of $\tau_{a}$ but they are more representative of the actual $\tau_{a}$ variations. Figure 7 shows the radiative efficiencies at TOA and surface as a function of $\theta_{0}$ for the various cases simulated: terrestrial surfaces with albedos representative of the Ispra area and the whole Po Valley (four seasons) and the Ispra aerosol model, and water cases with both AAOT and Ispra aerosol models and a very reflective surface (snow) with the Ispra aerosol model.

As documented in previous studies (e.g., Nemesure et al., 1995; Boucher, 1998b), the dependence on the solar zenith angle of the ADRE at the top of atmosphere (Fig. 7a) displays a well marked (negative) maximum at intermediate solar zenith angles. $\delta F^{\mathrm{TOA}}$ is lower at low $\theta_{0}$, as the relative contribution of the aerosols in absorbing surface-reflected radiation (thus decreasing the overall efficiency of the atmospheresurface system in reflecting the solar radiation) is larger. As anticipated in the previous section, the dependence of the ADRE at TOA is clearly affected by the characteristics of the surface. For $\theta_{0}$ below $60^{\circ}, f_{e}^{\mathrm{TOA}}$ for the marine cases is higher (more negative) than for terrestrial surfaces, illustrating the main dependence of the ADRE with respect to surface albedo (e.g., Charlson et al., 1992; Haywood and Shine, 1995). This is particularly the case at low solar zenith angle. At $20^{\circ}, f_{e}^{\mathrm{TOA}}$ is equal to $-54 \mathrm{~W} \mathrm{~m}^{-2} \tau_{a}^{-1}$ over water with the AAOT aerosol model. The maximum $f_{e}^{\mathrm{TOA}}$ is found at $55^{\circ}\left(-68 \mathrm{~W} \mathrm{~m}^{-2} \tau_{a}^{-1}\right.$ for the AAOT aerosol case), angle lower than that documented by Boucher and Tanré (2000), 


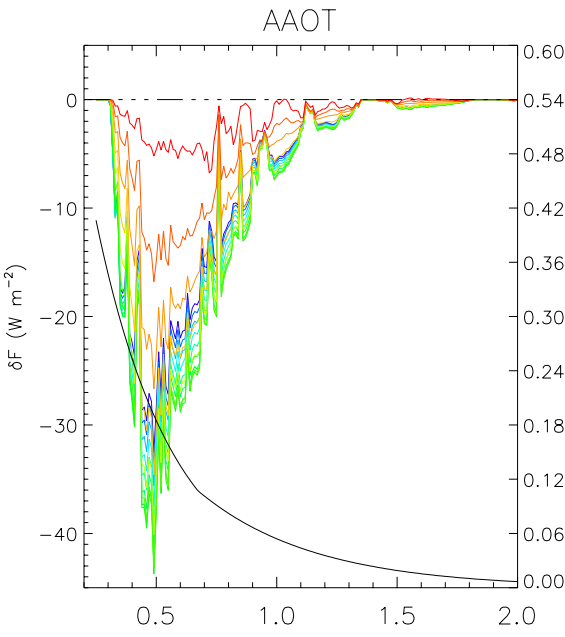

(a)

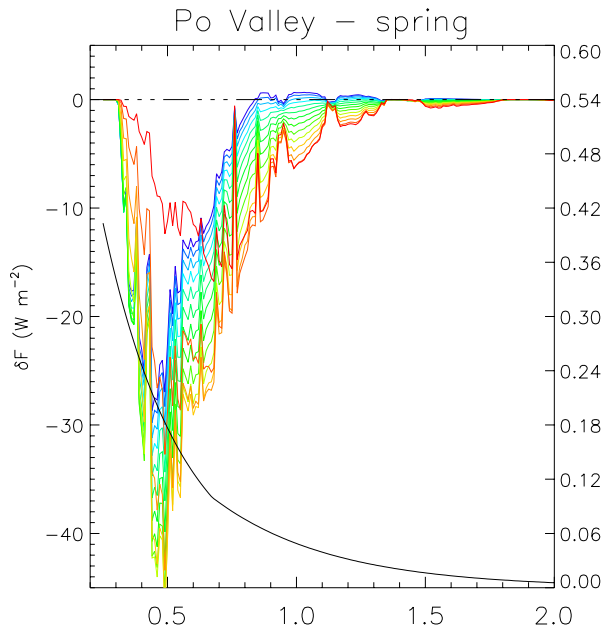

(b)

Fig. 8. Spectral dependency of $\delta F^{\mathrm{TOA}}$ obtained for the reference $\tau_{a}$ bin for increasing values of the solar zenith angle ranging from $20^{\circ}$ (blue) to $85^{\circ}$ (red), for the cases of the AAOT site (a) and the Po Valley in spring (b). The reference $\tau_{a}$ is shown by the black line.

a shift that might be due to the aerosol types and a different treatment of the bidirectional reflectance of the water surface. A more absorbing aerosol, like that associated with Ispra, decreases $f_{e}^{\text {TOA }}$ by approximately $4 \mathrm{~W} \mathrm{~m}^{-2} \tau_{a}^{-1}$. For solar zenith angles higher than $60^{\circ}, f_{e}^{\mathrm{TOA}}$ decreases sharply, as the water surface reflectivity rises according to the Fresnel law. Over the Po Valley, $f_{e}^{\mathrm{TOA}}$ is lowest at $20^{\circ}$, especially for the more reflecting case, in spring and summer, with $-20 \mathrm{~W} \mathrm{~m}^{-2}$ $\tau_{a}^{-1}$ (a factor of almost 3 with respect to the equivalent marine case). The maximum efficiency is observed for $\theta_{0}^{\max }$ of $65-70^{\circ}$ and ranges from -54 to $-59 \mathrm{~W} \mathrm{~m}^{-2} \tau_{a}^{-1}$ from winter to summer surface albedos. These values increase (more negative) for a less reflecting surface, like that found around Ispra. Over a very bright surface (snow), $f_{e}^{\text {TOA }}$ becomes positive, with a maximum at low $\theta_{0}\left(+150 \mathrm{~W} \mathrm{~m}^{-2} \tau_{a}^{-1}\right.$ at $20^{\circ}$ ). These values are in line with the findings in Ricchiazzi et al. (2005) for a continental aerosol type $\left(+18 \mathrm{~W} \mathrm{~m}^{-2}\right.$ for $\tau_{a}(550)=0.1$ at the same $\theta_{0}$ ).

At the surface (Fig. 7b), the efficiencies $f_{e}^{\text {SRF }}$ appear rather constant for $\theta_{0}$ up to $60^{\circ}$, for all cases but the snow albedo, and all values are found in the range -107 to $-135 \mathrm{~W} \mathrm{~m}^{-2}$ $\tau_{a}^{-1}$, for $\theta_{0}$ lower than $70^{\circ}$. For higher angles, the $f_{e}^{\mathrm{SRF}}$ curves converge towards smaller radiative effects. For all simulations, $f_{e}^{\mathrm{SRF}}$ is maximum (negative) for $\theta_{0}^{\max }$ between $55^{\circ}$ and $60^{\circ}$. The location of this maximum depends only slightly on the surface reflectivity or aerosol model. For the marine case, the maximum $f_{e}^{\mathrm{SRF}}$ amounts to -123 and $-135 \mathrm{~W} \mathrm{~m}^{-2} \tau_{a}^{-1}$ for the AAOT and Ispra aerosol models, respectively, and it ranges from -132 to $-134 \mathrm{~W} \mathrm{~m}^{-2} \tau_{a}^{-1}$ for the Po Valley with different seasonal albedos. Two factors appear important in determining the amplitude of the surface ADRE for a given $\tau_{a}$. The radiative efficiency at the surface decreases (less negative) for more reflecting surfaces which is particulary visible for the snow case, showing a minimum of $-45 \mathrm{~W} \mathrm{~m}^{-2} \tau_{a}^{-1}$ at $20^{\circ}$. It increases for more absorbing aerosols, for instance by approximately $15 \%$ (for $\theta_{0}$ up to $60^{\circ}$ ) if the AAOT aerosol model is substituted by the Ispra model used over a marine surface.

Similarly, the radiative efficiencies can be computed for a day by combining the instantaneous contributions for each sun zenith angle with the actual solar illumination cycle during the day. As for the linear regression performed on instantaneous values, only the first $13 \tau_{a}$ bins are considered. Table 2 presents the radiative efficiencies $f_{e}$ for both sites, computed for the 21 st of every month. Logically, $f_{e}$ values are identical at the two equinoxes for the AAOT site (this is not so for the Po Valley because of the seasonal cycle of the surface albedo). At AAOT from December to June, $f_{e}^{\mathrm{TOA}}$ ranges from -15 to $-32 \mathrm{~W} \mathrm{~m}^{-2} \tau_{a}^{-1}$ and $f_{e}^{\mathrm{SRF}}$ from -35 to $-65 \mathrm{~W} \mathrm{~m}^{-2} \tau_{a}^{-1}$. For the Po Valley, $f_{e}^{\mathrm{SRF}}$ exhibits a larger seasonal variability from winter to summer (from -33 to $-72 \mathrm{~W} \mathrm{~m}^{-2} \tau_{a}^{-1}$ ) while, interestingly, the annual variations of $f_{e}^{\mathrm{TOA}}$ are lower, between -17 and $-24 \mathrm{~W} \mathrm{~m}^{-2} \tau_{a}^{-1}$. In fact at TOA, the longer duration of the day in summer, which increases the daily ADRE, is balanced over land by the much reduced effectiveness around noon (low $\theta_{0}$, see Fig. $7 \mathrm{a}$ and Fig. 9 in Sect. 3.1.4).

Other estimates of the aerosol direct radiative effect are listed in Table 3 for regions mostly or partly influenced by continental/anthropogenic aerosols (these examples do not include situations with mostly dust or marine aerosols). Importantly, part of the variability of efficiency values given in Table 3 is due to differences in modelling and experimental approaches (including the spectral interval considered), in surface characteristics, in latitude, or in temporal scales. Notwithstanding this diversity, a comparison with this study 

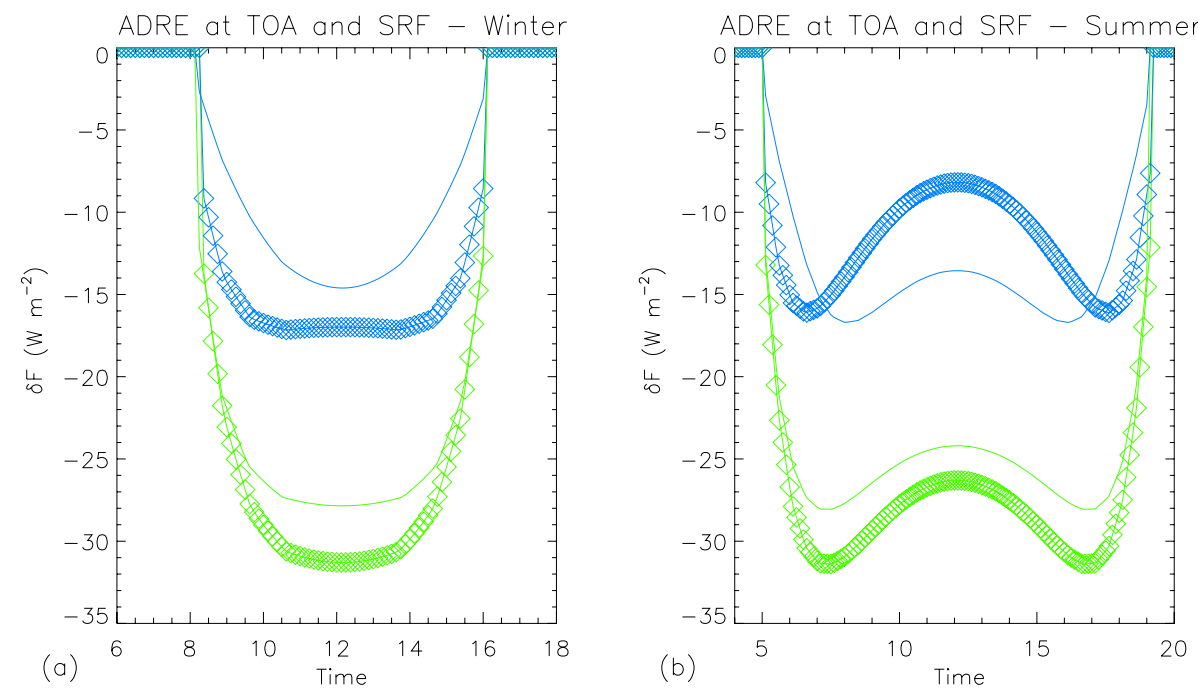

Fig. 9. Diurnal cycle of the aerosol direct radiative effect, computed for the reference bin $\left(\tau_{a} \simeq 0.21\right)$ for $15 \mathrm{January}$ (a) and July (b). $\delta F^{\mathrm{TOA}}$ (blue) and $\delta F^{\mathrm{SRF}}$ (green) are represented for the Po Valley (line+diamonds) and the AAOT (line) cases.

Table 2. Daily aerosol direct radiative effect efficiencies at TOA and surface, for the 21 st of every month, for the AAOT site and the Po Valley case. Units are $\mathrm{W} \mathrm{m}^{-2} \tau_{a}(500)^{-1}$.

\begin{tabular}{lllll}
\hline & \multicolumn{2}{c}{ AAOT } & \multicolumn{2}{c}{ Po Valley } \\
Month & $f_{e}^{\mathrm{TOA}}$ & $f_{e}^{\mathrm{SRF}}$ & $f_{e}^{\mathrm{TOA}}$ & $f_{e}^{\mathrm{SRF}}$ \\
\hline January & -17.2 & -38.6 & -19.5 & -38.8 \\
February & -22.6 & -46.5 & -23.0 & -49.3 \\
March & -26.7 & -53.1 & -22.3 & -57.5 \\
April & -29.7 & -59.1 & -23.1 & -64.8 \\
May & -31.7 & -63.6 & -23.7 & -69.9 \\
June & -32.5 & -65.4 & -24.4 & -72.0 \\
July & -31.7 & -63.6 & -24.0 & -69.9 \\
August & -29.6 & -59.0 & -23.3 & -64.6 \\
September & -26.7 & -53.1 & -23.2 & -57.7 \\
October & -22.3 & -46.1 & -21.4 & -48.5 \\
November & -16.9 & -38.3 & -18.2 & -38.1 \\
December & -14.8 & -34.8 & -17.3 & -33.4 \\
\hline
\end{tabular}

places the present estimates of ADRE in relation to aerosols and their radiative impacts in other regions. The radiative efficiencies documented in this work appear in the middle of the interval represented in Table 3 and are actually similar to various situations. For instance, both $f_{e}^{\mathrm{TOA}}$ and $f_{e}^{\mathrm{SRF}}$ for the Po Valley compare remarkably well with estimates given for the region of Vienna (Austria) in summer. Interestingly, they are also similar to the values documented for Kanpur (India). The radiative efficiencies obtained for the AAOT site can be favorably compared to other estimates given for northeastern Greece, the marine regions around Korea and Japan, or southwest of India in (boreal) winter-spring. The ratio of daily $f_{e}$ at surface and TOA varies for the Po Valley case from 1.9 (December) to 3.0 (June) with an annual average of 2.5. It varies in the interval 2.0 to 2.4 for the AAOT case (annual mean of 2.1). The present results are also consistent with the multi-site analysis of Zhou et al. (2005). These calculations and the comparisons with other ADRE estimates confirm a situation of moderately absorbing aerosols, coherent with the single scattering albedos characterizing the area.

\subsubsection{Spectral dependence of the aerosol direct radiative ef- fect}

As discussed above, the effect of the surface reflectivity in determining the radiative effect is particularly marked at the top of atmosphere (Fig. 7), and can be further described in terms of its spectral distribution (Fig. 8, example given for the reference $\tau_{a}$ at the two sites). Obviously, for a given $\theta_{0}$, the spectral distribution of the radiative effect is a combination of the solar irradiance spectrum and the spectral characteristics of the surface albedo and aerosol optical thickness.

As seen on Fig. 7a, the radiative effect for the AAOT case increases slightly from $20^{\circ}$ to $50^{\circ}$ and then decreases clearly for $\theta_{0}$ beyond $60^{\circ}$. This reduction is due to an increase of the surface reflectivity with $\theta_{0}$ and appears to be uniformly distributed on the $\delta F^{\mathrm{TOA}}$ spectrum (see Fig. 8a, orange to red curves). For the Po Valley the initial increase of $\delta F$ is steeper and decreases only at high solar zenith angles. As expected for aerosols of continental type, the radiative effect for wavelengths larger than $1 \mu \mathrm{m}$ becomes negligible. Actually, most of the radiative energy changes are distributed in the spectral interval $0.4-0.8 \mu \mathrm{m}$. For the Po Valley, the marked increase in albedo from 0.5 to $0.9 \mu \mathrm{m}$ results in a decrease of the negative radiative effect, that becomes even positive for small $\theta_{0}$ values in the spectral range 0.75 to $1.3 \mu \mathrm{m}$. Except at very high solar zenith angles, the largest radiative impact is for wavelengths around $0.5 \mu \mathrm{m}$ (corresponding to the maximum of solar irradiance). 
Table 3. Daily aerosol direct radiative efficiencies. The fourth column $(\lambda)$ indicates the spectral domain considered (SW: shortwave broadband). The fifth column gives the observed $\tau_{a}$ and the associated wavelength, also used for the normalization of ADRE. All wavelengths are in $\mu \mathrm{m}$. Units for $f_{e}$ are $\mathrm{W} \mathrm{m}^{-2} \tau_{a}^{-1}$.

\begin{tabular}{lllllll}
\hline Area & Surface & Period & $\lambda$ & $\tau_{a}$ & $f_{e}^{\text {TOA }}$ & $f_{e}^{\text {SRF }}$ \\
\hline Lindenberg [1] & land & July-August & $0.2-4$ & $0.08-0.25(0.55)$ & -48 & -67 \\
Almería [2] & land & June & $0.44-0.78$ & $0.41(0.52)$ & -11 & -57 \\
Vienna [2] & land & & $0.44-0.78$ & $0.39(0.52)$ & -24 & -68 \\
Marseilles [3] & land & June-July & $0.3-3$ & $0.23-0.45(0.5)$ & $\sim-24$ & -107 \\
NE Greece [4] & sea & Aug & $0.28-4$ & $0.39(0.5)$ & $-21 /-18$ & $-55 /-63$ \\
NE Greece [4] & sea/land & August & $0.28-4$ & $0.39(0.5)$ & $-12 /-8$ & $-49 /-56$ \\
Crete [5] & sea/land & July-August & SW & $0.1-0.5(0.5)$ & -31 & -85 \\
Sede Boker [6] & land & year & $0.17-2.27$ & $(0.55)$ & $-32 /-12$ & $-68 /-56$ \\
Lampedusa [7] & sea/land & May & $0.4-0.7$ & $0.164(0.53)$ & -4 & -122 \\
US E. Coast [8] & sea & July & SW & $(0.55)$ & -30 & -87 \\
US E. Coast [9] & sea & July & SW & $(\mathrm{VIS})$ & $-53 /-44$ & $-96 /-68$ \\
East. US [10] & land & June-July & SW & $(\mathrm{SW})$ & -20 & \\
US [11] & land & spr-sum. & SW & $(\mathrm{SW})$ & $-33 /-23$ & \\
N. America [12] & land & year & SW & $(\mathrm{SW})$ & $\sim-25$ & \\
Gosan [13] & sea/land & April & SW & $(0.5)$ & & -73 \\
Sea of Japan [14] & sea & April & SW & $0.43 \pm 0.25(0.5)$ & -27 & -60 \\
Gosan [15] & sea/land & November & SW & $0.12-0.28(0.5)$ & & -79 \\
NE Asia [16] & sea & Apr & $0.3-4$ & $(0.5)$ & $-29 /-18$ & $-69 /-90$ \\
Kaashidhoo [17] & sea & January-March & SW & $0.1-0.7(0.5)$ & -25 & -73 \\
Bay of Bengal [18] & sea & October & SW & $0.43(0.5)$ & -33 & -59 \\
SW India [19] & sea & March-April & $0.25-4$ & $0.44 \pm 0.13$ & $-29 /-22$ & $-59 /-72$ \\
Bangalore [20] & land & October-December & SW & $0.24(0.5)$ & +21 & -97 \\
Kanpur [21] & land & December-January & $0.25-4$ & $(0.5)$ & -25 & -72 \\
\hline
\end{tabular}

References and notes: [1] Wendling et al. (2002): Lindenberg (Germany), $80 \mathrm{~km} \mathrm{SE} \mathrm{Berlin;} \mathrm{[2]} \mathrm{Horvath} \mathrm{et} \mathrm{al.} \mathrm{(2002):} \mathrm{Almería} \mathrm{(coastal}$ Spain), and Vienna (Austria); calculations are with respect to a background aerosol load; [3] Roger et al. (2006): Marseilles (SE France), albedo from MODIS; [4] Formenti et al. (2002): 2 values for 2 aerosol models; [5] Markowicz et al. (2002): includes cases of forest fire aerosols; [6] Derimian et al. (2006): annual average of $\tau_{a}(500)=0.20 \pm 0.11$; the radiative effect applies to the downwelling fluxes and is computed for the contribution of pollution aerosols only; maximum $f_{e}^{\text {TOA }}\left(-32 \mathrm{~W} \mathrm{~m}^{-2} \tau_{a}(550)^{-1}\right)$ is found in February-March, minimum $(-12)$ in May-June, maximum $f_{e}^{\mathrm{SRF}}\left(-68 \mathrm{~W} \mathrm{~m}^{-2} \tau_{a}(550)^{-1}\right)$ is found in March, minimum (-56) in November; [7] Meloni et al. (2003): computed for the case of 27 May 1999 (day with aerosol of northern origin, with highest Ångström exponent, 1.36), with $\tau_{a}(532)$ from Di Iorio et al. (2003); [8]: Hignett et al. (1999): US East Coast (TARFOX campaign); [9]: Russel et al. (1999): US East Coast (TARFOX campaign) with TARFOX aerosol models and $\tau_{a}$ averaged in the interval 0.3-0.7 $\mu \mathrm{m}$ (VIS); [10] Im et al. (2001): North Carolina (US), calculations with a box model; [11] Sheridan and Ogren (1999): central and eastern US, calculations with a box model; [12] Delene et al. (2002): central US, Alaska, Nova Scotia (Canada), calculations with a box model; [13] Bush and Valero (2003): Gosan, Island of Jeju (S Korea), ACE-Asia; [14] Markowicz et al. (2003): ACE-Asia; [15] Kim et al. (2005a): Gosan, Island of Jeju (S Korea), pollution event; [16] Kim et al. (2005b): measurements at Anmyon and Gosan (S Korea), and Amami-Oshima Island (Japan), only the non-dust cases are used here; [17] Satheesh and Ramanathan (2000): Kaashidhoo Island, SW of India; [18] Sumanth et al. (2004): coastal Bay of Bengal; [19] Moorthy et al. (2005): coastal SW India; [20] Babu et al. (2002) Bangalore (India); [21] Dey and Tripathi (2007): Kanpur (N India).

\subsubsection{Diurnal cycle of the aerosol direct radiative effect}

The diurnal cycle of $\delta F^{\mathrm{TOA}}$ and $\delta F^{\mathrm{SRF}}$ is derived by combining the radiative effect, computed for every solar zenith angle, with the $\theta_{0}$ variations during 15 January (winter) and 15 July (summer). At this stage, the aerosol optical thickness is fixed at its reference value. In winter, at the latitude of both sites, $\theta_{0}$ remains close to or larger than $\theta_{0}^{\max }$ and the maximum $\delta F^{\mathrm{TOA}}$ and $\delta F^{\mathrm{SRF}}$ are reached during the central part of the day (Fig. 9a). In summer $\delta F^{\mathrm{SRF}}$ is maximum around 07:00 a.m. and 05:00 p.m. and exhibits a visible reduction during the central part of the day (Fig. 9b). At TOA the same effect is visible, with maxima slightly shifted in time, due to a different dependence of the ADRE on $\theta_{0}$ (Fig. 7). The daily cycle of $\delta F^{\mathrm{TOA}}$ is especially evident for the Po Valley, with a maximum of about $-16 \mathrm{~W} \mathrm{~m}^{-2}$ early in the morning and late in the afternoon, which is about twice as much as the value at noon. These results are associated with a decrease of the hemispheric upscatter fraction and have been documented in the context of other measurement series (e.g., Russel et al., 1999; Formenti et al., 2002; Wendling et al., 2002).

\subsection{Sensitivity analysis}

Sensitivity tests are here performed to assess the uncertainty of the ADRE estimates. The main sources of uncertainty in the radiative effect estimation are linked to the optical properties of the aerosols and their vertical distribution, in the sea/land surface reflectivity parametrization and in some approximations introduced at different steps of the calculation. 

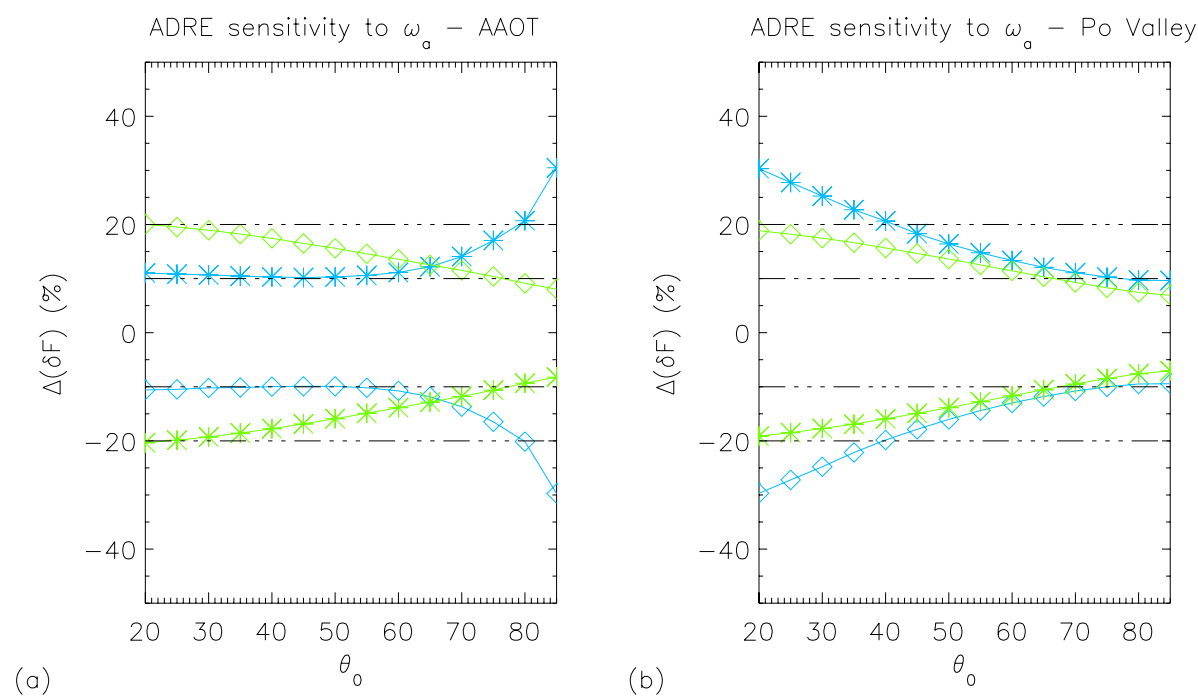

Fig. 10. Percentage variation of $\delta F^{\mathrm{TOA}}$ (blue) and $\delta F^{\mathrm{SRF}}$ (green) for $\omega_{a}=\omega_{a}+\delta \omega_{a}$ (asterisks) and $\omega_{a}=\omega_{a}-\delta \omega_{a}$ (diamonds), for the AAOT and Po Valley reference cases.

The effect of these sources is discussed and quantified below, to be used for an overall uncertainty budget.

\subsubsection{Aerosol optical thickness}

The expected accuracy of the aerosol optical thickness at $500 \mathrm{~nm}$ is 0.015 (Eck et al., 1999). This uncertainty has a different impact for low and high aerosol loads, resulting, e.g, in a relative error of more than $40 \%$ for the first bin (low $\tau_{a}$ ) and around $2 \%$ for the last bin of the aerosol models, while it amounts to approximately $7 \%$ for the average values. In the uncertainty budget, the relationship between $\tau_{a}$ and $\delta F$ is assumed linear, so that the related uncertainty on the radiative effect, $\Delta_{\tau}$, is equal to first order to the ratio $\delta \tau_{a} / \tau_{a}$. Part of this uncertainty is due to calibration and might result in a bias during a deployment period, whereas assumptions on the atmospheric conditions (e.g., pressure, ozone) lead to a variable error term (Eck et al., 1999).

\subsubsection{Single scattering albedo}

In the RT simulations, the single scattering albedo $\omega_{a}$ is assumed as a constant spectrum (see Sect. 2.2). For a sensitivity analysis, the uncertainty on $\omega_{a}, \sigma_{\omega}$, is estimated as the maximum of the dispersion around the mean value (standard deviation reported in Table 1) and 0.03, which is the uncertainty associated with the inversion process (Dubovik et al., 2000). Admittedly, there is an additional, unknown, uncertainty due to the absence of $\omega_{a}$ values associated with conditions of low aerosol loads. As for $\omega_{a}$, the uncertainty term $\sigma_{\omega}$ is extrapolated to all wavelengths in the range 0.25 to $2.0 \mu \mathrm{m}$. Then, the radiative effect associated with aerosols having single scattering albedo equal to $\omega_{a}(\lambda) \pm \sigma_{\omega}(\lambda)$ has been computed for representative $\tau_{a}$ bins and the conditions associated with AAOT and the Po Valley, assuming a season- ally averaged spectral surface albedo for the latter. The relative differences, with respect to the ADRE computed with the average $\omega_{a}$, are represented on Fig. 10, for the reference $\tau_{a}$ bin. It is underlined here that all $\delta F$ at TOA and surface observed in the present study are negative, snow cases excepted, and a positive relative difference (in\%) means a reinforced negative effect.

For the AAOT site and the reference $\tau_{a}(500)(0.219)$, $\delta F^{\mathrm{TOA}}$ increases (more negative) for the more scattering aerosol (case $\omega_{a}+\sigma_{\omega}$ ), within $15 \%$ for $\theta_{0}$ below $70^{\circ}$ and by up to $20-30 \%$ for high $\theta_{0}$ (see Fig. 10a). On the other hand, at the surface this less absorbing aerosol results in a radiative effect that is reduced by $-20 \%$ to $-8 \%$ for $\theta_{0}$ from $20^{\circ}$ to $85^{\circ}$. The effect of a more absorbing aerosol (case $\omega_{a}-\sigma_{\omega}$ ) gives specular results both at TOA and surface. These relative differences are little affected by the aerosol load: with $\tau_{a}$ as high as 0.6 , the relative differences do not change by more than $3-4 \%$, except for $\delta F^{\mathrm{TOA}}$ at $\theta_{0}$ of $85^{\circ}(8 \%)$. For the Po Valley case and the reference $\tau_{a}(500)(0.211)$ (Fig. 10b) the relative change in $\delta F^{\mathrm{TOA}}$ due to a change in $\omega_{a}$ is maximum for low $\theta_{0}\left(30 \%\right.$ at $\left.20^{\circ}\right)$ and decreases to $\pm 10 \%$ for high $\theta_{0}$. A significant impact of $\tau_{a}$ is noticed for $\delta F^{\mathrm{TOA}}$, particularly at low solar zenith angles: the relative differences for $\theta_{0}$ equal to $20^{\circ}$ is in the interval $25-35 \%$ but may reach $45 \%$ for high $\tau_{a}(0.65)$. The trend for $\delta F^{\mathrm{SRF}}$ is very similar to that described for AAOT, from $19 \%$ to $7 \%$ as $\theta_{0}$ increases. As $\tau_{a}$ is varied, the relative differences for $\delta F^{\mathrm{SRF}}$ change by approximately $2 \%$.

In the following, the reference $\tau_{a}(500)$ serves to define a typical uncertainty term due to $\omega_{a}$. The relative sensitivity of $\delta F$ with respect to the uncertainty on $\omega_{a}$ depends clearly on $\theta_{0}$, both in magnitude and variations (including between sites), and this dependence is kept in the following error treatment. 


\subsubsection{Scattering phase function}

In the aerosol models defined in Sect. 2.2, and unlike the assumption of a fixed $\omega_{a}$ spectrum, the evolution of the aerosol scattering phase function $\psi_{a}$ with the aerosol load, expressed by the $\tau_{a}$ bin (Fig. 4), is taken into account in the set of RT calculations. The uncertainties of the ADRE associated with the uncertainties on $\psi_{a}$ are assessed by considering the variations of $\psi_{a}$ in an aerosol model bin. First, the logarithmic distance between each $\psi_{a}$ (taken at $670 \mathrm{~nm}$ ) included in the bin and the bin-averaged function is evaluated, and the curves are sorted accordingly (the distance is computed as the root mean square difference between log-transformed values of $\psi_{a}$ over the available scattering angles). Then two sets of $\psi_{a}$ are selected, each containing $10 \%$ of the bin population, and centered around the 16 and 84 percentiles of the distance distribution (i.e., at \pm one standard deviation of the average $\left.\psi_{a}\right)$. The respective averages of these two sets, noted $\psi_{a, 1}$ and $\psi_{a, 2}$ (see Fig. 11 for the AAOT case) are considered representative of the phase function dispersion and provide an estimate of the associated uncertainty. Interestingly, $\psi_{a, 1}$ exhibits reduced forward and backward scattering peaks, and an increased scattering for scattering angles in the range 10 to $70^{\circ}$, and is associated with high $\tau_{a}$ values in the bin; $\psi_{a, 2}$ shows an opposite behavior. Numerically, large differences are noticed in the very first angles of scattering, but this variation of the forward scattering peak does not have a large impact on the aerosol radiative effect.

Calculations have been performed with $\psi_{a, 1}$ and $\psi_{a, 2}$ for the AAOT and terrestrial conditions and for various bins, and the relative difference, noted $\Delta_{\psi}$, with respect to the standard results is computed. In practice, $\Delta_{\psi}$ varies with the phase function used, the type of surface, $\tau_{a}$ and $\theta_{0}$ in a rather complex way. For the sake of quantifying the related uncertainty term, the average relative effect during a day is computed for the central day of every season by considering the $\theta_{0}$ variations; this appears confined within $4 \%$ (2\%) for the Po Valley (AAOT) case at TOA and $1.5 \%$ at surface for both cases. These upper boundaries are conservatively chosen as estimate of $\Delta_{\psi}$. These low values are explained by the fact that the aerosol type encountered in the region is fairly stable; the introduction of $\psi_{a}$ representative of very different aerosol types is likely to have a much larger impact.

\subsubsection{Influence of the aerosol vertical distribution}

The diversity characterizing the vertical distribution of aerosols have been amply documented in various locations (e.g., Hartley et al., 2000; Redemann et al., 2003; Matthias et al., 2004). To assess the impact of this variability on the aerosol radiative effect, RT calculations have been conducted with three exponential vertical distributions, defined so that the amount of particles reaches $90 \%$ of the total at heights of 1,2 and $3 \mathrm{~km}$, and are compared with the results of the reference distribution (uniform up to $3 \mathrm{~km}$ ). For these sim-

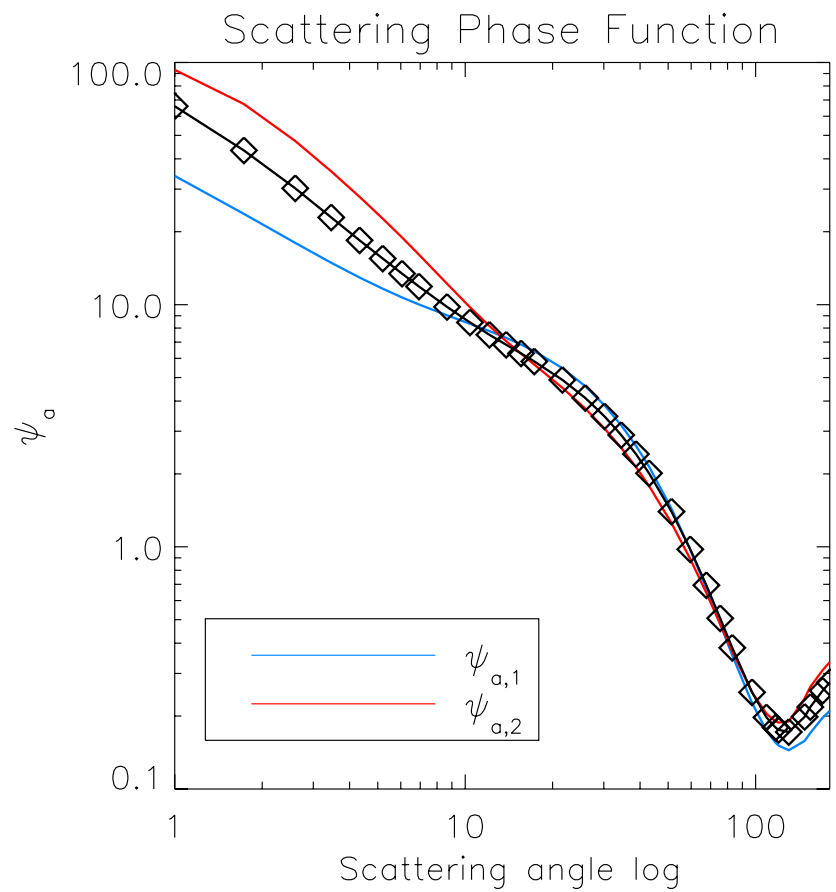

Fig. 11. Definition of the range of variation of $\psi_{a}$ for the central $\tau_{a}$ bin, at the AAOT site.

ulations, the vertical resolution is refined to $250 \mathrm{~m}$ in the lower $3 \mathrm{~km}$. The inherent optical properties of the aerosols are still maintained constant. Even though such tests are far from representing the full diversity of the observed aerosol layering, an exponential function has been used as a convenient way of depicting its main features for typical continental aerosols, including at European sites (e.g., Mattis et al., 2004; De Tomasi et al., 2006). On the other hand, complex vertical layering has been found for particular events, such as long range transport of desert dust or forest fire aerosols (including over Europe, for instance see Ansmann et al., 2004; Mattis et al., 2003, respectively), that are not the focus of the present study.

The results of the simulations performed for the reference $\tau_{a}$ are represented on Fig. 12 as relative differences with respect to the reference case (aerosol uniform up to $3 \mathrm{~km}$ ). As expected, the largest relative differences $\Delta_{z}$ in radiative effect occur at TOA when the aerosol particles are concentrated close to the surface (90\% of the aerosol load within $1 \mathrm{~km}$ ) and for the highest solar zenith angles $(-3 \%$ and $-6 \%$ for $\theta_{0}$ of $75^{\circ}$ and $80^{\circ}$, respectively). $\delta F^{\mathrm{SRF}}$ exhibits a moderate dependence on the vertical distribution, with relative differences mostly within $1 \%$ for $\theta_{0}$ below $80^{\circ}$. The change in vertical structure usually has a larger effect for the terrestrial case, particularly for low $\theta_{0},(+4.5 \%$ at TOA and $-1.5 \%$ at the surface, i.e., a more and less negative radiative effect, respectively). The increases in $\Delta_{z}$ noticeable for very large $\theta_{0}$ should be considered with caution because of the approximation of a plane-parallel atmosphere in the RT calculations. In any case, these higher values are related to situations of low 

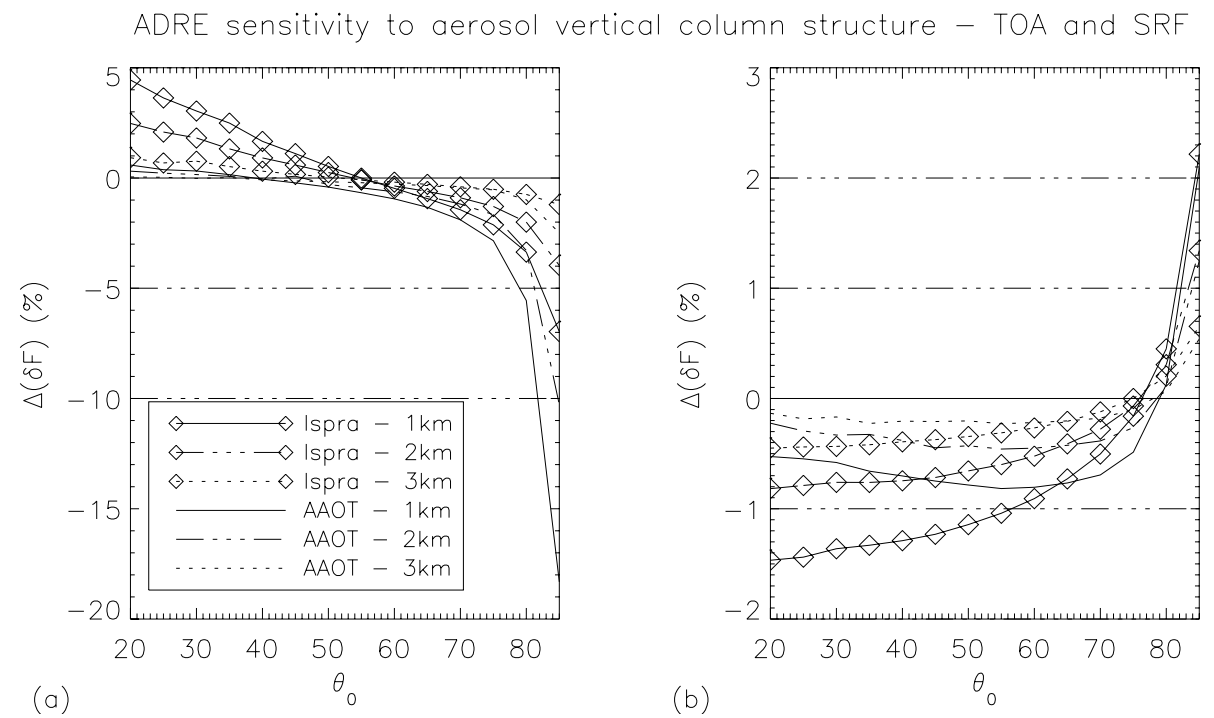

Fig. 12. Percentage variation of $\delta F^{\mathrm{TOA}}$ (a) and $\delta F^{\mathrm{SRF}}$ (b) for different aerosol vertical distributions. RT calculations with an exponential distribution with $90 \%$ of particles within $1 \mathrm{~km}, 2 \mathrm{~km}$ and $3 \mathrm{~km}$ are compared with the reference case (uniform distribution up to $3 \mathrm{~km}$ ).

solar irradiance. Similar results are obtained for higher $\tau_{a}$.

The estimate of the daily average effect of different vertical distributions is done by combining $\Delta_{z}$ of the $1-\mathrm{km}$ exponential profile (worst case) with the $\theta_{0}$ variation during the central day of each season. The result is within $3.4 \%$ at TOA and about $1 \%$ at the surface, and these values are used in the following uncertainty budget. Even though these results indicate a secondary effect of the aerosol vertical structure, it is stressed that they apply to the integrated effect (at TOA and surface). The vertical structure of the aerosol radiative effect, whose description is relevant for an accurate modelling of atmospheric dynamics, is obviously affected more strongly by the vertical distribution of the aerosols.

\subsubsection{Influence of the surface albedo}

The land surface albedo averaged over the region in proximity to the Ispra AERONET station exhibits values lower than the average for the whole Po Valley, for every season and for both black and white-sky albedos (Fig. 5). The spectral albedo, used as input to the RT model, is computed by weighting black and white sky albedos with the direct-todiffuse irradiance ratio, which depends on $\theta_{0}$ and $\tau_{a}$. Consequently, the relative difference between the albedos $\rho$ of the two regions also depends on $\theta_{0}$ and $\tau_{a}$, but in practice the related variations are small. Actually, for all conditions and seasons, relative differences between albedos associated with Ispra and the Po Valley (for $\rho$ integrated between 0.25 and $2 \mu \mathrm{m}$ ) are found between 19\% (in spring) and 22\% (in winter).

As already seen on Fig. $7, \delta F$ is larger (more negative) in the case of an albedo representative of the region of Ispra than for the (higher) albedo averaged over the whole Po Valley. This is particularly visible for $\delta F^{\mathrm{TOA}}$ in conditions of high values of $\tau_{a}$ and low solar zenith angles. The effect on ADRE at TOA, estimated along the central day of each season, is within $6 \%$ (winter) and $12 \%$ (spring), while, at the surface, it is much reduced, with differences not exceeding $2 \%$.

Considering the geographical variability of the surface conditions encountered in the area of study (Fig. 1), the differences between the two sets of simulations appear appropriate to depict the sensitivity of $\delta F$ to variations of $\rho$. Thus the relative uncertainty of $\delta F$ due to the uncertainty on $\rho$, noted $\Delta_{\rho}$, can be directly estimated by scaling the differences between the two sets of simulations with the absolute accuracy characterizing the MODIS product $( \pm 0.02$, Sect. 2.3). The dependence of $\Delta_{\rho}$ on $\theta_{0}$ is conserved in the estimates of the uncertainty budget for $\delta F$. Typically, the resulting uncertainties on the daily time scale are on average less than $1 \%$ for $\delta F^{\mathrm{SRF}}$ and vary between $3.6 \%$ and $6.8 \%$ from winter to summer for $\delta F^{\mathrm{TOA}}$. Admittedly, these values do not foresee specific ground conditions such as heavy snow cover or flooded rice paddy fields that can be found in the western Valley.

For the marine conditions, RT calculations have been performed with different wind speeds, including 1 and $10 \mathrm{~m} \mathrm{~s}^{-1}$. The resulting relative differences vary mostly with $\theta_{0}, \sim 5-$ $10 \%$ at the top of atmosphere and $1 \%$ at the surface. Conservatively, an uncertainty of $10 \%$ is assumed for $\delta F^{\mathrm{TOA}}$. This appears consistent with the assumptions made by $\mathrm{Yu}$ et al. (2004).

\subsubsection{Influence of the diurnal cycle}

In all calculations so far, the aerosol optical thickness was taken constant during the day. This is justified for the sake of simplicity and the fact that time resolved daily series of $\tau_{a}$ are 

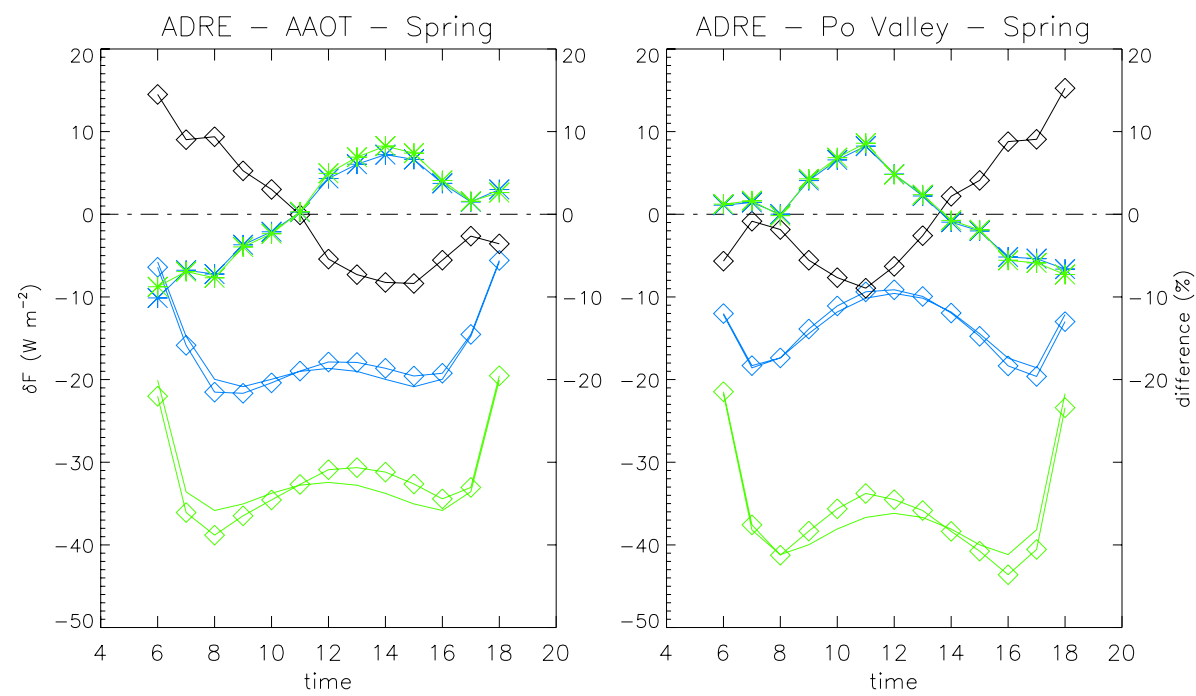

Fig. 13. Influence on the aerosol direct radiative effect of the diurnal cycle of $\tau_{a} . \delta F^{\mathrm{TOA}}$ (blue) and $\delta F^{\mathrm{SRF}}$ (green) are computed for the two cases using constant daily values for $\tau_{a}$ (line), and a diurnally-resolved $\tau_{a}$ (line with diamonds). The $\delta F$ scale is on the left-hand side. The associated relative differences of $\delta F$ are shown by the corresponding colored lines with asterisks and the relative diurnal variability of $\tau_{a}$ is in black with diamonds (right-hand axis).

not always available for the determination of the aerosol radiative effect. However, $\tau_{a}$ values measured at both sites exhibit significant diurnal variations (Mélin and Zibordi, 2005). The related impact on the radiative effect is here assessed, for each season, by comparing $\delta F$ computed for $\tau_{a}$ assumed constant along the day and varying according to the seasonally averaged diurnal cycle, computed as by Smirnov et al. (2002) (see Fig. 13 for the example of spring and the reference $\tau_{a}$ ). The relative differences in radiative effect, $\Delta_{d}$, mirror the $\tau_{a}$ variations along the day. Daily averages of $\delta F$ are always within $0.8 \%$ for the AAOT site and aerosol model, due to compensation of morning and evening $\tau_{a}$ variations. This is not so in the case represented by Ispra, where $\tau_{a}$ around noon tends to be lower than the daily average. Consequently, $\Delta_{d}$ is higher, up to $1.9 \%$ and $2.1 \%$ in winter, for TOA and surface, respectively. Clearly, daily variations of $\tau_{a}$ much larger than the seasonal average might occur, but in general the use of a constant $\tau_{a}$ (equal to the daily average) for computing the daily integrated $\delta F$ seems a safe approximation, favored by the quasi linearity of $\delta F$ versus $\tau_{a}$.

\subsubsection{Overall uncertainty budget}

The different sources of uncertainty described above and their impact on $\delta F^{\mathrm{TOA}}$ and $\delta F^{\mathrm{SRF}}$ are combined in order to derive an estimate of the uncertainty at daily and monthly scales (see Sect. 4.1 and Sect. 4.2). The various uncertainty terms described above and assumed independent are summed to estimate the uncertainty $\Delta_{D}$ for the daily aerosol radiative effect $\delta F$ :

$$
\Delta_{D}=\left(\Delta_{\tau}^{2}+\Delta_{\omega}^{2}+\Delta_{\psi}^{2}+\Delta_{z}^{2}+\Delta_{\rho}^{2}+\Delta_{d}^{2}\right)^{1 / 2} .
$$

For the monthly ADRE averages, we distinguish between "random" errors, which can be minimized when considering repeated measurements on the same site, and "systematic" error contributions, that are not reduced by averaging. The uncertainties associated with the variations of aerosol optical properties $\left(\omega_{a}\right.$ and $\left.\psi_{a}\right)$ in a bin are assumed variable, whereas the uncertainties associated with methodological assumptions (fixed homogeneous vertical distribution and constant $\tau_{a}$ during the day) and with the characteristics of the surface albedo are assumed systematic. Uncertainties on $\tau_{a}$ are partly due to uncertainties on environmental variables (pressure, ozone, ...) and calibration. The latter term might result in a systematic error during a deployment period. Conservatively, it is assumed to be dominant (see Eck et al., 1999, for a discussion) and thus systematic. Therefore, the error on the monthly average is computed as:

$\Delta_{M}=\left(\Delta_{\tau}^{2}+\frac{\Delta_{\omega}^{2}}{\mathrm{~N}_{d}}+\frac{\Delta_{\psi}^{2}}{\mathrm{~N}_{d}}+\Delta_{z}^{2}+\Delta_{\rho}^{2}+\Delta_{d}^{2}\right)^{1 / 2}$

where $\mathrm{N}_{d}$ is the number of days available in the month.

\section{Estimates of the aerosol direct radiative effect}

\subsection{Daily statistics}

The available AERONET time series described in Sect. 2.1 serve for the computation of the clear sky aerosol direct radiative effect along the entire time period. For regional studies, it is important to consider the whole frequency distribution of the aerosol load, and not only monthly or seasonal averages; these smooth out events that potentially have a strong 

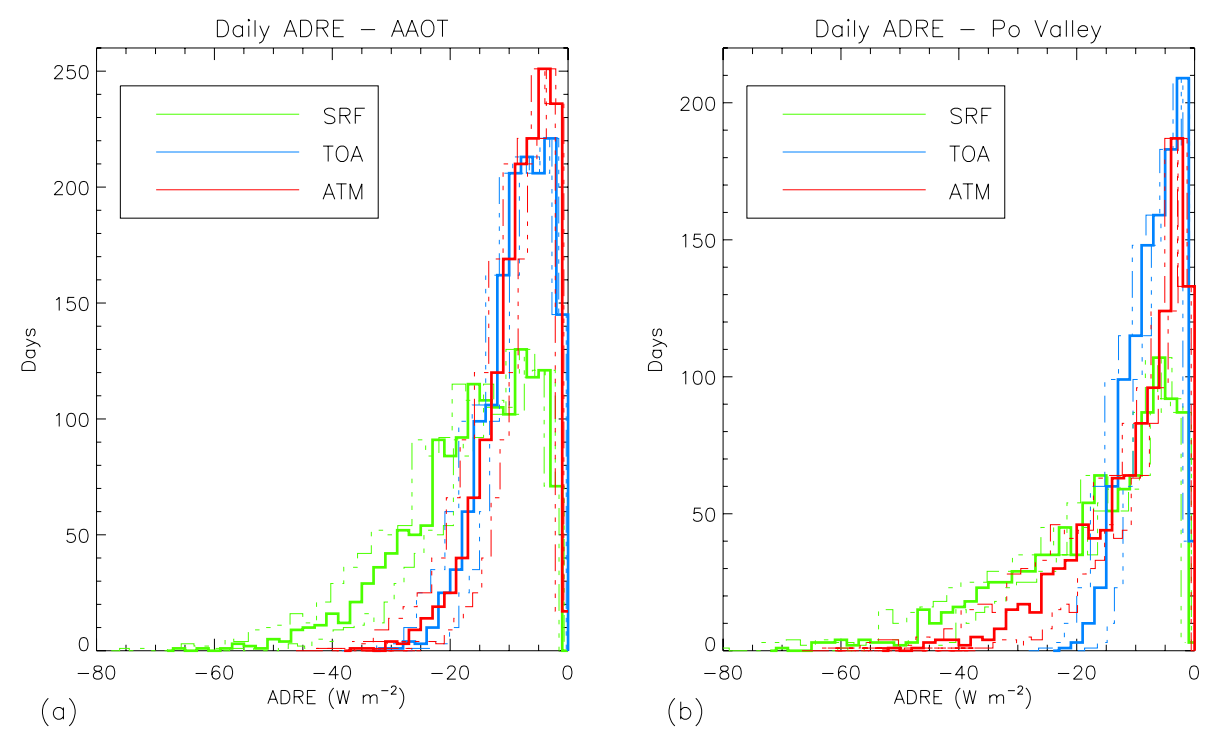

Fig. 14. Frequency distributions (in number of clear-sky days) of $\delta F^{\mathrm{TOA}}$ (blue), $\delta F^{\mathrm{SRF}}$ (green) and $\delta F^{\mathrm{ATM}}$ (red) occurrences, for the AAOT (a) and Po Valley (b) cases. The dashed lines bracketing each quantile of daily estimates represent the corresponding uncertainty. The arithmetic averages for the AAOT site of $\delta F^{\mathrm{TOA}}, \delta F^{\mathrm{SRF}}$ and $\delta F^{\mathrm{ATM}}$ are $-8.4,-16.6$ and $+8.3 \mathrm{~W} \mathrm{~m}^{-2}$, respectively; for the Po Valley case, they are $-6.7,-17.3$ and $+10.6 \mathrm{~W} \mathrm{~m}^{-2}$ (see Sect. 4.1 for geometric means).

impact on the radiative budget (besides the statistics on air quality monitoring). Estimates of ADRE are performed for clear sky days with an associated value of $\tau_{a}(500)$. Here these are arbitrarily defined as the days with a minimum number of optical measurements during the day, proportional to the day length, from 12 in June to 6 in December. These thresholds affect the number of days classified as clear but not the main statistical features of the ADRE frequency distribution represented on Fig. 14. The dashed lines bracketing each quantile of daily estimates represent the corresponding uncertainty, computed as in Eq. $1\left(\delta F \pm \Delta_{D} \delta F\right)$. The results presented for the terrestrial case are derived from the LUT constructed with the typical albedo for the Po Valley and the Ispra aerosols. As anticipated earlier, the aerosols at Ispra are here considered representative of the conditions in the western part of the Valley; considering the relative homogeneity of the surface conditions for the region of interest (Fig. 1), it seems more relevant for the present regional analysis to select the corresponding albedo. In any case, the ADRE for the actual site of Ispra differs only slightly. Finally, in line with the hypothesis of a $\log$-normal distribution for $\tau_{a}$, $\log$-transformed statistics for $\delta F$ are preferred to describe the frequency distributions (arithmetic means are given for completeness in the legend of Fig. 14).

At the AAOT site (1497 days classified as clear sky), $\delta F^{\mathrm{SRF}}$ amounts on average to $-13.0 \mathrm{~W} \mathrm{~m}^{-2}$ with extreme values up to $-60 \mathrm{~W} \mathrm{~m}^{-2}$ in summer. The $\delta F^{\mathrm{TOA}}$ distribution is centered around $-6.5 \mathrm{~W} \mathrm{~m}^{-2}$ and ranges up to $-30 \mathrm{~W} \mathrm{~m}^{-2}$. The ratio of surface and TOA ADRE is in the range 1.8 to 2.5 with average equal to 2.0. For conditions representative of the western Po Valley (1050 days classified as clear sky), $\delta F^{\mathrm{SRF}}$ and $\delta F^{\mathrm{TOA}}$ are -12.2 and $-5.2 \mathrm{~W} \mathrm{~m}^{-2}$, with the highest values beyond $-70 \mathrm{~W} \mathrm{~m}^{-2}$ and $-20 \mathrm{~W} \mathrm{~m}^{-2}$, respectively. With respect to the AAOT site, the higher values at the surface are mainly due to the lower $\omega_{a}$, while at TOA the effect is reduced due to the surface albedo. The ratio of $\delta F^{\mathrm{SRF}}$ and $\delta F^{\mathrm{TOA}}$ amounts on average to 2.4 and exhibits a large variability (1.6 to 3.7$)$, which can be attributed to a larger variability in $\omega_{a}$ and the variations of the surface albedo during the year. If similar statistics are computed by season, the geometric averages for $\delta F^{\mathrm{SRF}}$ vary for both sites between approximately -6 and $-19 \mathrm{~W} \mathrm{~m}^{-2}$ from winter to summer. This evolution for $\delta F^{\mathrm{TOA}}$ is from -2.7 to $-9.9 \mathrm{~W} \mathrm{~m}^{-2}$ for AAOT, and -3.2 to $-7.1 \mathrm{~W} \mathrm{~m}^{-2}$ for the Po Valley case.

For the AAOT site, the average error terms for $\delta F^{\mathrm{SRF}}$ and $\delta F^{\mathrm{TOA}}$ are $18 \%$ (or $2.7 \mathrm{~W} \mathrm{~m}^{-2}$ ) and $20 \%$ (or $1.5 \mathrm{~W} \mathrm{~m}^{-2}$ ), respectively. The average error for $\delta F^{\mathrm{SRF}}$ for the Po Valley is $19 \%\left(2.6 \mathrm{~W} \mathrm{~m}^{-2}\right)$; the relative error for $\delta F^{\mathrm{TOA}}$ is $23 \%$ $\left(1.3 \mathrm{~W} \mathrm{~m}^{-2}\right)$, a figure higher than at AAOT due to the higher sensitivity on $\omega_{a}$. For both sites, the uncertainties on $\tau_{a}$ and $\omega_{a}$ contribute to most of the overall uncertainty for $\delta F^{\mathrm{SRF}}$ (approximately more than $90 \%$ ) and in comparable proportions (even though varying with site and season). For $\delta F^{\mathrm{TOA}}$, the other error terms take more importance, particularly the uncertainty due to the surface albedo. The latter is assumed as $10 \%$ for marine surfaces and is on average around $5 \%$ for land conditions (see Sect. 3.2.5).

The average atmospheric radiative effect $\delta F^{\mathrm{ATM}}$, computed as $\delta F^{\mathrm{TOA}}-\delta F^{\mathrm{SRF}}$, is found slightly higher for the terrestrial conditions $\left(+6.8 \mathrm{~W} \mathrm{~m}^{-2}\right)$ than at AAOT $\left(+6.5 \mathrm{~W} \mathrm{~m}^{-2}\right)$, a difference mostly induced by a weaker 
$\delta F^{\mathrm{TOA}}$ favored by a higher surface reflectivity. The long time series offer the unique opportunity to give an estimate of the spatial gradient in radiative effect due to aerosols at the scale of the Po Valley. As a simplification, the days classified as clear for both sites (673) are considered as the sample population to compute the gradient in atmospheric radiative effect (see Fig. 15 for the frequency distribution). These estimates are based only on differences between sites located at two ends of the Po Valley, but even though larger gradients might be observed locally in between, they provide an interesting insight into the spatial distribution of $\delta F^{\mathrm{ATM}}$ at a regional scale. The gradient is mostly positive towards Ispra (larger heating) with an overall average of $3.8 \mathrm{~W} \mathrm{~m}^{-2}$. Actually, $\delta F^{\mathrm{ATM}}$ appears larger in the Po Valley conditions in $65 \%$ of the cases. This is only partly explained by a larger $\tau_{a}$ (in 55\% of the cases). Differences in $\omega_{a}$ and surface boundary conditions further modulate the atmospheric radiative gradient; in fact the daily radiative efficiency for the atmosphere, $f_{e}^{\mathrm{ATM}}$, averaged over the same population, appears higher for the Po Valley conditions, $38 \mathrm{~W} \mathrm{~m}^{-2} \tau_{a}^{-1}$ versus $31 \mathrm{~W} \mathrm{~m}^{-2} \tau_{a}^{-1}$ for the AAOT site. The average of the absolute differences $\mid \delta F^{\mathrm{ATM}}$ (Po Valley) $-\delta F^{\mathrm{ATM}}(\mathrm{AAOT}) \mid$ is $6.3 \mathrm{~W} \mathrm{~m}^{-2}$ (or $2.1 \mathrm{~W} \mathrm{~m}^{-2}$ per $100 \mathrm{~km}$ ), and regularly exceed $10 \mathrm{~W} \mathrm{~m}^{-2}$ (in $23 \%$ of the cases).

\subsection{Seasonal analysis}

Subsequently, monthly averages of the aerosol radiative effect are derived from the daily series. Then, the average seasonal cycle is computed using the available years and is combined with the cloud fraction CF (provided by the International Satellite Cloud Climatology Project, Rossow and Schiffer, 1999) to yield the monthly climatology of the aerosol direct radiative effect. Figure 16 represents $\delta F^{\mathrm{TOA}}$, $\delta F^{\mathrm{SRF}}$ and $\delta F^{\mathrm{ATM}}$, together with a $\pm \sigma$ bar representing the inter-annual variations around the climatological average (also weighted by the clear-sky fraction). The aerosol optical depth at $500 \mathrm{~nm}$ and the clear-sky fraction are also displayed. At the AAOT site, $\delta F^{\mathrm{SRF}}$ increases from winter $\left(-1.7 \mathrm{~W} \mathrm{~m}^{-2}\right.$ in December) to summer $\left(-12.9 \mathrm{~W} \mathrm{~m}^{-2}\right.$ in August), a seasonal excursion reinforced by the correlated seasonal cycles of clear-sky fraction and sun illumination. The ADRE at the top-of-atmosphere exhibits the same seasonal behavior, ranging from -0.7 to $-6.6 \mathrm{~W} \mathrm{~m}^{-2}$ for the same months. Consequently, the atmospheric heating, coming from the difference of the terms above, presents again a minimum in December $\left(+1.0 \mathrm{~W} \mathrm{~m}^{-2}\right)$ and a maximum in August $\left(+6.3 \mathrm{~W} \mathrm{~m}^{-2}\right)$. The seasonal trend derived for the Po Valley region is similar, with $\delta F^{\mathrm{SRF}}$ increasing from winter $\left(-1.9 \mathrm{~W} \mathrm{~m}^{-2}\right.$ in December) to summer $\left(-13.7 \mathrm{~W} \mathrm{~m}^{-2}\right.$ in June $)$, and similarly with $\delta F^{\mathrm{TOA}}$ increasing from $-1.0 \mathrm{~W} \mathrm{~m}^{-2}$ in December to $-4.8 \mathrm{~W} \mathrm{~m}^{-2}$ in July. The atmospheric heating is as high as $+9.1 \mathrm{~W} \mathrm{~m}^{-2}$ in June, and is minimum in December $\left(0.9 \mathrm{~W} \mathrm{~m}^{-2}\right)$. For both cases, the error budget represented by $\Delta_{M}$ (Eq. 2) amounts to ap-

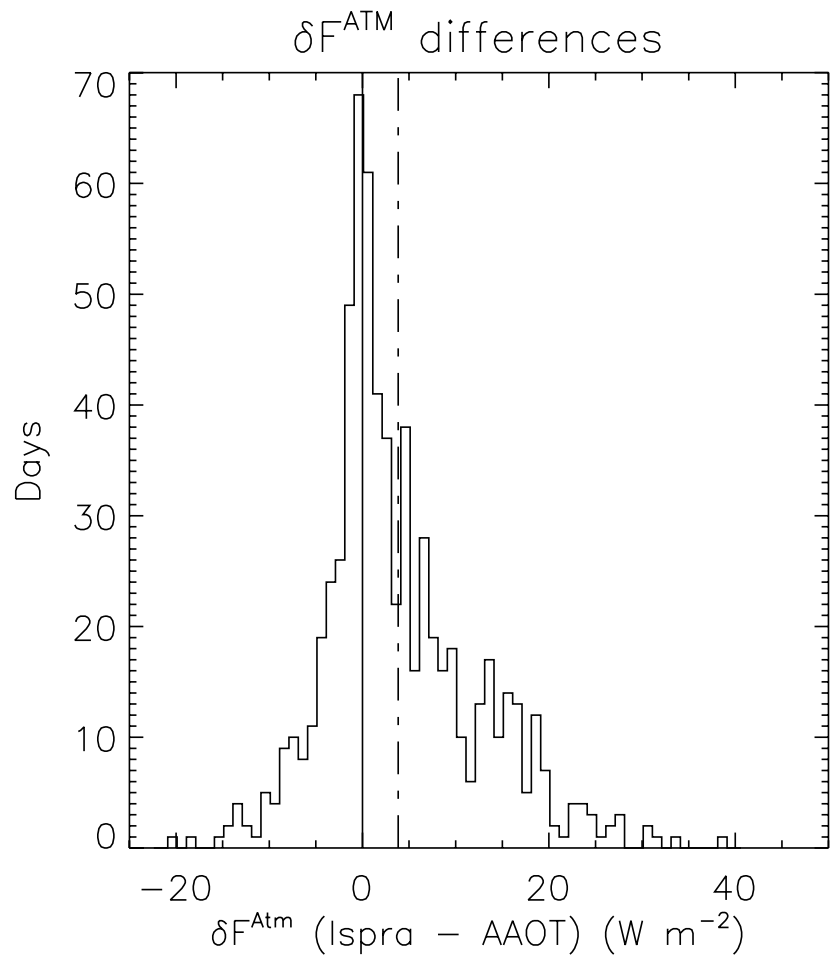

Fig. 15. Frequency distributions (in number of common clear-sky days) of the differences between the aerosol direct radiative effect for the atmosphere $\delta F^{\mathrm{ATM}}$ between the Po Valley and AAOT cases.

proximately $13 \%$ in winter and $3-5 \%$ in summer. The higher value of the monthly uncertainty term in winter is explained by a lower number of days during winter months and the lower average $\tau_{a}$ in that season, leading to higher relative uncertainties.

\section{Conclusions}

The direct radiative effect induced by aerosols is computed for the Po Valley region and the adjacent North Adriatic Sea, from long term time series of AERONET measurements and MODIS albedo data. For the sites of AAOT and Ispra, the overall averages for $\tau_{a}(500)$ and $\alpha$ are approximately 0.21 and 1.51, respectively. Besides the nature of the surface, the main difference between the two sites is a higher absorption for the Ispra aerosols, with an average $\omega_{a}(440)$ of $0.928 \pm 0.032$, as compared to AAOT's $0.956 \pm 0.017$.

The different surface reflectivity over land and sea concurs to significant differences in radiative efficiencies $f_{e}$ at TOA (Fig. 7 and Table 2), varying for daily values along the year from -17 to $-24 \mathrm{~W} \mathrm{~m}^{-2} \tau_{a}^{-1}$ for the inner Po Valley conditions, and from -15 to $-32 \mathrm{~W} \mathrm{~m}^{-2} \tau_{a}^{-1}$ for the AAOT case. The efficiency at surface is more similar between sites in amplitude and temporal dependence, a convergence favored by a compensation between the effects of different $\omega_{a}$ and 

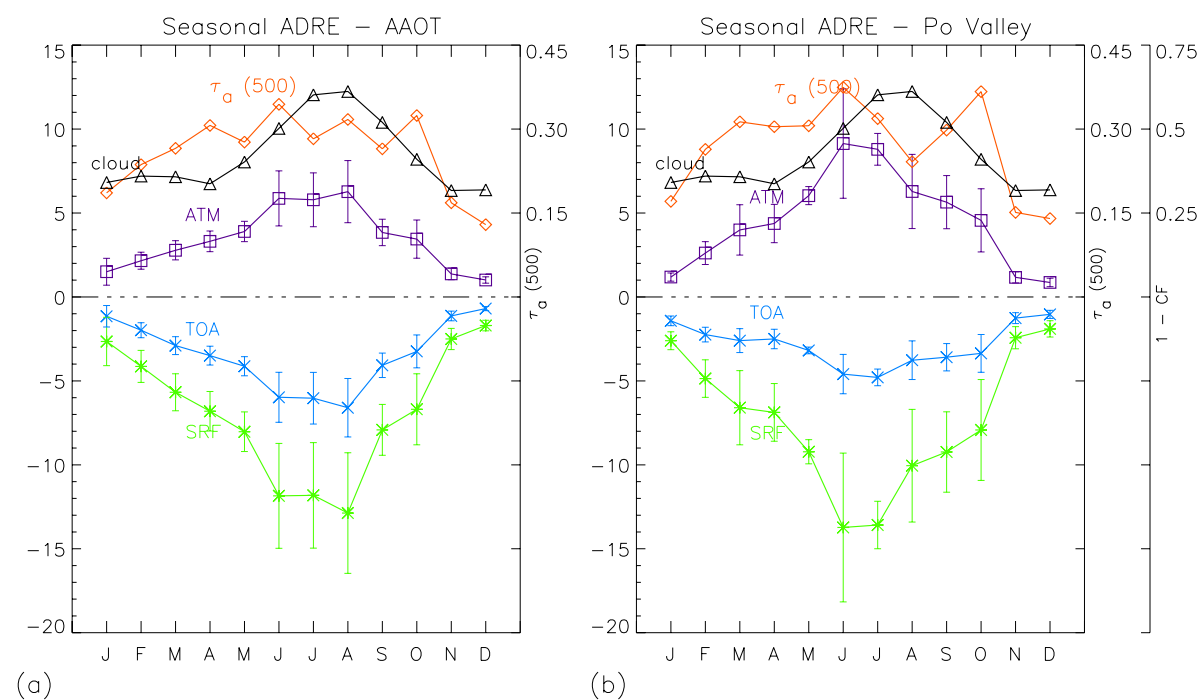

(b)

Fig. 16. Monthly average $\delta F^{\mathrm{TOA}}$ (blue), $\delta F^{\mathrm{SRF}}$ (green), $\delta F^{\mathrm{ATM}}$ (violet), $\tau_{a}$ (orange) and the clear-sky fraction (1-CF), for the AAOT (a) and Po Valley (b) cases. The left-hand axis is for the $\delta F$ terms; specific axis are on the right-hand side for $\tau_{a}$ and the clear-sky fraction.

surface conditions (see Fig. 7). The variations from December to June for $f_{e}^{\mathrm{SRF}}$ are -33 to $-72 \mathrm{~W} \mathrm{~m}^{-2} \tau_{a}^{-1}$ for the Po Valley case and -35 to $-65 \mathrm{~W} \mathrm{~m}^{-2} \tau_{a}^{-1}$ for the AAOT site. In terms of daily radiative effect, the frequency distributions of $\delta F^{\mathrm{TOA}}, \delta F^{\mathrm{SRF}}$ and $\delta F^{\mathrm{ATM}}$ have a geometric average of $-5.2,-12.2$ and $+6.8 \mathrm{~W} \mathrm{~m}^{-2}$, respectively, for the Po Valley case, and $-6.5,-13.0$ and $+6.5 \mathrm{~W} \mathrm{~m}^{-2}$ for the marine site. On any given day, these radiative effects can be much higher (see Fig. 14). Furthermore, the large data set available gives the opportunity of analyzing a representative frequency distribution of the atmospheric heating spatial gradient between two ends of the Po Valley created by the aerosols in clear-sky conditions. This gradient is skewed towards a larger heating in the western part of the Valley and its average absolute value amounts to $6.3 \mathrm{~W} \mathrm{~m}^{-2}$. Finally, a monthly climatology has been derived using seasonal values of the clear-sky fraction. For the Po Valley case, the climatological ADRE at TOA and surface peaks in summer at values of -4.8 and $-13.7 \mathrm{~W} \mathrm{~m}^{-2}$, respectively. The corresponding values for the AAOT site are -6.6 and $-12.9 \mathrm{~W} \mathrm{~m}^{-2}$. All these results point to a significant role of the aerosols in the radiative budget of the region.

An attempt has been made to accompany the estimates of the clear sky aerosol radiative effect in the region by a comprehensive uncertainty budget. The sources of uncertainty considered are mostly related to the measurements or determination of aerosol optical properties $\left(\tau_{a}, \omega_{a}\right.$ and $\left.\psi_{a}\right)$, the construction of the aerosol models (with properties either constant or varying dynamically with the aerosol load), assumptions on the aerosol vertical distribution, and the surface reflectivity. Not surprisingly, the uncertainties on $\tau_{a}$ and $\omega_{a}$ usually dominate the error budget, but secondary terms, like that associated with the surface conditions, are also sig- nificant contributors particularly for the TOA effect. The uncertainty on the daily values has been estimated to be overall of the order of $20 \%$. It is underlined that this uncertainty analysis is restricted to the framework of clear sky estimates. The global effect of aerosols on the region needs to include all interactions between aerosols and clouds but these complex and multi-faceted effects have not been considered in the present study. The integration of complementary measurements and chemical and transport modelling into a comprehensive monitoring system would be a logical avenue towards an improved assessment of the regional climate.

In any case, the emergence of a decade-long record of aerosol data obtained from optical measurements contributes to a better definition of the radiative budget of the Po Valley and adjacent marine area. This is relevant in the context of reduced emissions in western Europe (particularly for sulfate; Stern, 2006; Manktelow et al., 2007) and possible remote influences from inter-continental transport. In the case of the Po Valley (as in most of western Europe), an inversion in the temporal trend of solar radiation has been noticed in the 1980s (from "dimming" to "brightening", Norris and Wild, 2007), with the recent decrease likely related to a lower aerosol burden. As the time series of the field measurements lengthens, it further supports, in conjunction with other monitoring efforts, the analyzes of long term evolution of the aerosol load and associated radiative effect in this region characterized by high aerosol levels. 
Acknowledgements. The AERONET project (NASA) is thanked for the continuous effort put into the quality assurance and processing of the sun-photometric data. Special thanks go to G. Zibordi, who manages the AERONET sites of AAOT and Ispra. The MODIS project at NASA Goddard Space Flight Center and the International Satellite Cloud Climatology Project are acknowledged for the distribution of the albedo product and cloud data (http://isccp.nasa.gov), respectively. We acknowledge the use of the libRadtran RT code, from B. Mayer and A. Kylling, and of the gas absorption parametrization from SBDART of the Institute for Computational Earth System Science, University of California, Santa Barbara, California. Snow albedo spectrum is from the Aster spectral library (http://speclib.jpl.nasa.gov/), reproduced from the ASTER Spectral Library through courtesy of the Jet Propulsion Laboratory, California Institute of Technology, Pasadena, California. Copyright (C1999, California Institute of Technology.

Edited by: K. Carslaw

\section{References}

Anderson, G. L., Clough, S. A., Kneizys, F. X., Chetwynd, J. H., and Shettle, E. P.: AFGL atmospheric concentration profiles (0120 km), AFGL-TR86-0110, Air Force Geophys. Lab., Hanscom Air Force Base, MA, USA, 1986.

Ansmann, A., Bösenberg, J., Chaikovsky, A., Comerón, A., Eckhardt, S., Eixmann, R., Freudenthaler, V., Ginoux, P., Komguem, L., Linné, H., López Márquez, M. A., Matthias, V., Mattis, I., Mitev, V., Müller, D., Music, S., Nickovic, S., Pelon, J., Sauvage, L., Sobolewsky, P., Srivastava, M. K., Stohl, A., Torres, O., Vaughan, G., Wandinger, U., and Wiegner, M.: Long-range transport of Saharan dust to northern Europe: The 11-16 October 2001 outbreak observed with EARLINET, J. Geophys. Res., 108, 4783, doi:10.1029/2003JD003757, 2004.

Babu, S. S., Satheesh, S. K., and Moorthy, K. K.: Aerosol radiative forcing due to enhanced black carbon at an urban site in India, Geophys. Res. Lett., 29, 1880, doi:10.1029/2002GL015826, 2002.

Barnaba, F. and Gobbi, G. P.: Aerosol seasonal variability over the Mediterranean region and relative impact of maritime, continental and Saharan dust particles over the basin from MODIS data in the year 2001, Atmos. Chem. Phys., 4, 2367-2391, 2004, http://www.atmos-chem-phys.net/4/2367/2004/.

Beirle, S., Platt, U., Wenig, M., and Wagner, T.: Highly resolved global distribution of tropospheric $\mathrm{NO}_{2}$ using GOME narrow swath mode data, Atmos. Chem. Phys., 4, 1913-1924, 2004, http://www.atmos-chem-phys.net/4/1913/2004/.

Bellouin, N., Boucher, O., Tanré, D., and Dubovic, O.: Aerosol absorption over the clear-sky oceans deduced from POLDER1 and AERONET observations, Geophys. Res. Lett., 30, 1748, doi:10.10292003GL017121, 2003.

Boucher, O.: On aerosol direct shortwave forcing and the HenyeyGreenstein phase function, J. Atmos. Sci., 55, 128-134, 1998.

Boucher, O., Schwartz, S. E., Ackerman, T. P., Anderson, T. L., Bergstrom, B., Bonnel, B., Chýlek, P., Dahlback, A., Fouquart, Y., Fu, Q., Halthore, R. N., Haywood, J. M., Iversen, T., Kato, S., Kinne, S., Kirkevåg, A., Knapp, K. R., Lacis, A., Laszlo, I., Mishchenko, M. I., Nemesure, S., Ramaswamy, V., Roberts,
D. L., Russell, P., Schlesinger, M. E., Stephens, G. L., Wagener, R., Wang, M., Wong, J., and Yang, F.: Intercomparison of models representing direct shortwave radiative forcing by sulfate aerosols, J. Geophys. Res., 103, 16979-16998, 1998.

Boucher, O. and Tanré, D.: Estimation of the aerosol perturbation to the Earth's radiative budget over oceans using POLDER satellite aerosol retrievals, Geophys. Res. Lett., 27, 1103-1106, 2000.

Bush, B. C. and Valero, F. P. J.: Surface aerosol radiative forcing at Gosan during the ACE-Asia campaign, J. Geophys. Res., 108, 8660, doi:10.1029/2002JD003233, 2003.

Charlson, R. J., Schwartz, S. E., Hales, J. M., Cess, R. D., Coakley, J. A., Hanses, J., and Hofmann, D. J.: Climate forcing by anthropogenic aerosols, Science, 255, 423-430, 1992.

Chazette, P., Randriamiarisoa, H., Sanak, J., Couvert, P., and Flamant, C.: Optical properties of urban aerosol from airborne and ground-based in situ measurements performed during the Etude et Simulation de la Qualité de l'air en Ile-deFrance (ESQUIF) program, J. Geophys. Res., 110, D02206, doi:10.1029/2004JD004810, 2005.

Chu, D. A., Kaufman, Y. J., Zibordi, G., Chern, J. D., Mao, J., Li, C. and Holben, B. N.: Global monitoring of air pollution over land from the Earth Observing System - Terra Moderate Resolution Imaging Spectroradiometer (MODIS), J. Geophys. Res., 108, 4661, doi:10.1029/2002JD003179, 2003.

Chung, C. E., Ramanathan, V., and Kiehl, J. T.: Effects of the South Asian absorbing haze on the northeast monsoon and surface-air heat exchange, J. Climate, 15, 2462-2476, 2002.

Cox, C. and Munk, W.: Measurement of the roughness of the sea surface from photographs of the Sun's glitter, J. Opt. Soc. Am., 44(11), 838-850, 1956.

Delene, D. J. and Ogren, J. A.: Variability of aerosol optical properties at four North American surface monitoring sites, J. Atmos. Sci., 59, 1135-1150, 2002.

Derimian, Y., Karnieli, A., Kaufman, Y. J., Andreae, M. O., Andreae, T. W., Dubovik, O., Maenhaut, W., Koren, I., and Holben, B. N.: Dust and pollution aerosols over the Negev desert, Israel: Properties, transport and radiative effect, J. Geophys. Res., 111, D05205, doi:10.1029/2005JD006549, 2006.

De Tomasi, F., Tafuro, A. M., and Perrone, M. R.: Height and seasonal dependence of aerosol optical properties over southeast Italy, J. Geophys. Res., 111, D10203, doi:10.1029/2005GL006779, 2006.

Dey, S. and Tripathi, S. N.: Estimation of aerosol optical properties and radiative effects in the Ganga basin, northern India, during the wintertime, J. Geophys. Res., 112, D03203, doi:10.1029/2006JD007267, 2007.

Di Iorio, T., di Sarra, A., Junkermann, W., Cacciani, M., Fiocco, G., Fuà, D.: Tropospheric aerosols in the Mediterranean: 1. Microphysical and optical properties, J. Geophys. Res., 108, 4316, doi:10.1029/2002JD002815, 2003.

Dubovik, O. and King, M. D.: A flexible inversion algorithm for retrieval of aerosol optical properties from Sun and sky radiance measurements, J. Geophys. Res., 105, 20 673-20 696, 2000.

Dubovik, O., Smirnov, A., Holben, B. N., King, M. D., Kaufman, Y. J., Eck, T. F., and Slutsker, I.: Accuracy assessments of aerosol optical properties retrieved from AERONET Sun and sky radiance measurements, J. Geophys. Res., 105, 9791-9806, 2000.

Dubovik, O., Holben, B. N., Eck, T. F., Smirnov, A., Kaufman, Y. J., King, M. D., Tanré, D., and Slutsker, I.: Variability of ab- 
sorption and optical properties of key aerosol types observed in worldwide locations, J. Atmos. Sci., 59, 590-608, 2002.

Eck, T. F., Holben, B. N., Reid, J. S., Dubovik, O., Smirnov, A., O'Neill, N. T., Slutsker, I., and Kinne, S.: The wavelength dependence of the optical depth of biomass burning, urban and desert dust aerosols, J. Geophys. Res., 104, 31 333-31 350, 1999.

Estellés, V., Martínez-Lozano, J. A., Utrillas, M. P., and Campanelli, M.: Columnar aerosol properties in Valencia (Spain) by ground-based Sun photometry, J. Geophys. Res., 112, D11201, doi:10.1029/2006JD008167, 2007.

Formenti, P., Boucher, O., Reiner, T., Sprung, D., Andreae, M. O., Wendisch, M., Wex, H., Kinred, D., Tzortziou, M., Varasas, A., and Zerefos, C.: STAAARTE-MED 1998 summer airborne measurements over the Aegean Sea. 2. Aerosol scattering and absorption and radiative calculations, J. Geophys. Res., 107, D21, 4551, doi:10.1029/2001JD001536, 2002.

Friedl, M. A., McIver, D. K., Hodges, J. C. F., Zhang, X. Y., Muchoney, D., Strahler, A. H., Woodcock, C. E., Gopal, S., Schneider, A., Cooper, A., Baccini, A., Gao, F., and Schaaf, C.: Global land cover mapping from MODIS: Algorithms and early results, Remote Sens. Environ., 83, 287-302, 2002.

Hansen, J. and Travis, L. D.: Light scattering in planetary atmospheres, Space Sci. Rev., 16, 527-610, 1974.

Hansen, J., Sato, M., and Ruedy, R.: Radiative forcing and climate response, J. Geophys. Res., 102, 6831-6864, 1997.

Hartley, W. S., Hobbs, P. V., Ross, J. L., Russell, P. B., and Livingstone, J. M.: Properties of aerosols aloft relevant to direct radiative forcing off the mid-Atlantic coast of the United States, J. Geophys. Res., 105, 9859-9885, 2000.

Haywood, J. M. and Shine, K. P.: The effect of anthropogenic sulfate and soot aerosol on the clear sky planetary radiation budget, Geophys. Res. Lett., 22, 603-606, 1995.

Hignett, P., Taylor, J. P., Francis, P. N., and Glew, M. D.: Comparison of observed and modeled direct aerosol forcing during TARFOX, J. Geophys. Res., 104, 2279-2287, 1999.

Holben, B. N., Eck, T. F., Slutker, I., Tanré, D., Buis, J. P., Setzer, A., Vermote, E., Reagan, J. A., Kaufman, Y. J., Nakajima, T., Lavenu, F., Jankowiak, I., and Smirnov, A.: AERONET - A federated instrument network and data archive for aerosol characterization, Remote Sens. Environ., 66, 1-16, 1998.

Holben, B. N., Tanré, D., Smirnov, A., Eck, T. F., Slutsker, I., Abuhassan, N., Newcomb, W. W., Schafer, J. S., Chatenet, B., Lavenu, F., Kaufman, Y. J., Vande Castle, J., Setzer, A., Markham, B., Clark, D., Frouin, R., Halthore, R., Karneli, A., O'Neill, N. T., Pietras, C., Pinker, R. T., Voss, K., and Zibordi, G.: An emerging ground-based aerosol climatology: Aerosol optical depth from AERONET, J. Geophys. Res., 106, 12 067$12097,2001$.

Horvath, H., Alados Arboledas, L., Olmo, F. J., Jovanović, O., Gangl, M., Kaller, W., Sánchez, C., Sauerzopf, H., and Seidl, S.: Optical characteristics of the aerosol in Spain and Austria and its effect on radiative forcing, J. Geophys. Res., 107, 4386, doi:10.1029/2001JD001472, 2002.

Im, J.-S., Saxena, V. K., and Wenny, B. N.: Temporal trends of black carbon concentrations and regional climate forcing in the southeastern United States, Atmos. Env., 35, 3293-3302, 2001.
Intergovernamental Panel on Climate Change (IPCC), Climate Change 2001, The Scientific Basis, edited by: Houghton, J. T., Ding, Y., Griggs, D. J., Noguer, M., Van der Linden, P. J., and Xiaosu, D., Cambridge Univ. Press, New York, 881 pp., 2001.

Jin, Y., Schaaf, C. B., Woodcock, C. E., Gao, F., Li, X., Strahler, A. H., Lucht, W., and Liang, S.: Consistency of MODIS surface bidirectional reflectance distribution function and albedo retrievals. 2. Validation, J. Geophys. Res., 108, 4159, doi:10.1029/2002JD002804, 2003.

Kiehl, J. T. and Briegleb, B. P.: The relative role of sulfate aerosols and greenhouse gases in climate forcing, Science, 260, 311-314, 1993.

Kim, S.-W., Yoon, S.-C., Jefferson, A., Ogren, J. A., Dutton, E. G., Won, J.-G., Ghim, Y. S., Lee, B.-I., and Han, J.-S.: Aerosol optical, chemical and physical properties at Gosan, Korea during Asian dust and pollution episodes in 2001, Atmos. Environ., 39, 39-50, 2005.

Kim, D.-H., Sohn, B.-J., Nakajima, T., and Takamura, T.: Aerosol radiative forcing over east Asia determined from ground-based solar radiation measurements, J. Geophys. Res., 110, D10S22, doi:10.1029/2004JD004678, 2005.

Kurucz, R. L.: Synthetic infrared spectra, Proceedings of the 154th Symposium of the International Astronomical Union, Tucson, 2-6 March 1992, in: Infrared Solar Physics, edited by: Rabin, D. M., Jefferies, J. T., and Lindsey, C., Kluwer, Dordrecht, The Netherlands, 523-531, 1992.

Lau, K. M., Kim, M. K., and Kim, K. M.: Asian summer monsoon anomalies induced by aerosol direct forcing: The role of the Tibetan Plateau, Clim. Dynam., 26, 855-864, 2006.

Lohmann, U. and Feichter, J.: Global indirect aerosol effects: A review, Atmos. Chem. Phys., 5, 715-737, 2005, http://www.atmos-chem-phys.net/5/715/2005/.

Lucht, W., Schaaf, C. B., and Strahler, A. H.: An algorithm for the retrieval of albedo from space using semiempirical BRDF models, IEEE T. Geosci. Remote, 38, 977-998, 2000.

Mallet, M., Roger, J. C., Depiau, S., Dubovik, O., and Putaud, J.-P.: Microphysical and optical properties of aerosol particles in urban zone during ESCOMPTE, Atmos. Res., 69, 73-97, 2003.

Manktelow, P. T., Mann, G. W., Carslaw, K. S., Spracklen, D. V., and Chipperfield, M. P.: Regional and global trends in sulfate aerosol since the 1980s, Geophys. Res. Lett., 34, L14803, doi:10.1029/2006GL028668, 2007.

Markowicz, K. M., Flatau, P. J., Ramana, M. V., Crutzen, P. J., and Ramanathan, V.: Absorbing Mediterranean aerosols lead to a large reduction in the solar radiation at the surface, Geophys. Res. Lett., 29, 1968, doi:10.1029/202GL015767, 2002.

Markowicz, K. M., Flatau, P. J., Quinn, P. K., Carrico, C. M., Flatau, M. K., Vogelmann, A. M., Bates, D., Liu, M., and Rood, M. J.: Influence of relative humidity on aerosol radiative forcing: An ACE-Asia experiment perspective, J. Geophys. Res., 108, 8662, doi:10.1029/2003JD003066, 2003.

Matsui, T. and Pielke, R. A.: Measurement-based estimation of the spatial gradient of aerosol radiative forcing, Geophys. Res. Lett., 33, L11813, doi:10.1029/2006GL025974, 2006. 
Matta, E., Facchini, M. C., Decesari, S., Mircea, M., Cavalli, F., Fuzzi, S., Putaud, J.-P., and Dell'Acqua, A.: Mass closure on the chemical species in size-segregated atmospheric aerosol collected in an urban area of the Po Valley, Italy, Atmos. Chem. Phys., 3, 623-637, 2003, http://www.atmos-chem-phys.net/3/623/2003/.

Matthias, V., Balis, D., Bösenberg, J., Eixmann, R., Iarlori, M., Komguem, L., Mattis, I., Papayannis, A., Papparlardo, G., Perrone, M. R., and Wang, X.: Vertical aerosol distribution over Europe: Statistical analysis of Raman lidar data from 10 European Aerosol Research Lidar Network (EARLINET) stations, J. Geophys. Res., 109, D18201, doi:10.1029/2004JD004638, 2004.

Mattis, I., Ansmann, A., Wandinger, U., and Müller, D.: Unexpectedly high aerosol load in the free troposphere over central Europe in spring/summer 2003, Geophys. Res. Lett., 30, 2178, doi:10.1029/2003GL018442, 2003.

Mattis, I., Ansmann, A., Müller, D., Wandinger, U., and Althausen, D.: Multiyear aerosol observations with dual-wavelength Raman lidar in the framework of EARLINET, J. Geophys. Res., 109, D13203, doi:10.1029/2004JD004600, 2004.

Mayer, B. and Kylling, A.: Technical Note: The libRadtran software package for radiative transfer calculations - Description and examples of use, Atmos. Chem. Phys., 5, 1855-1877, 2005, http://www.atmos-chem-phys.net/5/1855/2005/.

Mélin, F. and Zibordi, G.: Aerosol variability in the Po Valley analyzed from automated optical measurements, Geophys. Res. Lett., 32, L03810, doi:10.1029/2004GL021787, 2005.

Mélin, F., Clerici, M., Zibordi, G., and Bulgarelli, B.: Aerosol variability in the Adriatic Sea from automated optical field measurements and Sea-viewing Wide Field-of-view Sensor (SeaWiFS), J. Geophys. Res., 111, D22201, doi:10.1029/2006JD007226, 2006.

Meloni, D., di Sarra, A., DeLuisi, J., Di Iorio, T., Fiocco, G., Junkermann, W., and Pace, G.: Tropospheric aerosols in the Mediterranean: 2. Radiative effects through model simulations and measurements, J. Geophys. Res., 108, 4317, doi:10.1029/2002JD002807, 2003.

Menon, S., Hansen, J., Nazarenko, L., and Luo, Y.: Climate effect of black carbon aerosols in China and India, Science, 297, 22502253, 2002.

Moody, E. G., King, M. D., Platnick, S., Schaaf, C. B., and Gao, F.: Spatially complete global spectral surface albedos: Valueadded datasets derived from Terra MODIS land products, IEEE T. Geosci. Remote, 43, 144-158, 2005.

Moorthy, K. K., Babu, S. S., and Satheesh, S. K.: Aerosol characteristics and radiative impacts over the Arabian Sea during the intermonsoon season: Results from ARMEX field campaign, J. Atmos. Sci., 62, 192-206, 2005.

Nemesure, S., Wagener, R., and Schwartz, S. E.: Direct shortwave forcing of climate by the anthropogenic sulfate aerosol: Sensitivity to particle size, composition, and relative humidity, J. Geophys. Res., 100, 26 105-26 116, 1995.

Norris, J. R. and Wild, M.: Trends in aerosol radiative effects over Europe inferred from observed cloud cover, solar "dimming", and solar "brightening", J. Geophys. Res., 112, D08214, doi:10.1029/2006JD007794, 2007.
O’Neill, N. T., Ignatov, A., Holben, B. N., and Eck, T. F.: The log-normal distribution as a reference for reporting aerosol optical depth statistics: Empirical tests using multi-year, multi-site AERONET sunphotometer data, Geophys. Res. Lett., 27, 33333336, 2000.

Perrone, M. R., Santese, M., Tafuro, A. M., Holben, B. N., and Smirnov, A.: Aerosol load characterization over South-East Italy for one year of AERONET sun-photometer measurements, Atmos. Res., 75, 111-133, 2005.

Putaud, J.-P., Van Dingenen, R., and Raes, F.: Submicron aerosol mass balance at urban and semi-rural sites in the Milan area (Italy), J. Geophys. Res., 107, 8198, doi:10.1029/2000JD000111, 2002.

Putaud, J.-P., Raes, F., Van Dingenen, R., Brüggemann, E., Facchini, M.-C., Decesari, S., Fuzzi, S., Gehrig, R., Hüglin, C., Laj, P., Lorbeer, G., Maenhaut, W., Mihalopoulos, N., Müller, K., Querol, X., Rodriguez, S., Schneider, J., Spindler, G., ten Brink, H., Tørseth, K., and Wiedensohler, A.: A European aerosol phenomenology. 2. Chemical characteristics of particulate matter at kerbside, urban, rural and background sites in Europe, Atmos. Environ., 38, 2579-2595, 2004.

Ramanathan, V., Crutzen, P. J., Kiehl, J. T., and Rosenfeld, D.: Aerosols, climate, and the hydrological cycle, Science, 249, 2119-2124, 2001.

Redemann, J., Turco, R. P., Liou, K. N., Hobbs, P. V., Hartley, W. S., Bergstrom, R. W., Browell, E. V., and Russell, P. B.: Case studies of the vertical structure of the direct shortwave aerosol radiative forcing during TARFOX, J. Geophys. Res., 105, 99719979, 2000.

Redemann, J., Masonis, S. J., Schmid, B., Anderson, T. L., Russell, P. B., Livingston, J. M., Dubovik, O., and Clarke, A. D.: Clearcolumn closure studies of aerosols and water vapor aboard the NCAR C-130 during ACE-Asia, 2001, J. Geophys. Res., 108, 8655, doi:10.1029/2003JD003442, 2003.

Remer, L. A. and Kaufman, Y. J.: Dynamic aerosol model: Urban/industrial aerosol, J. Geophys. Res., 103, 13 859-13 871, 1998.

Ricchiazzi, P., Yang, S., Gautier, C., and Sowle, D.: SBDART: A research and teaching software tool for plane-parallel radiative transfer in the Earth's atmosphere, Bull. Am. Meteorol. Soc., 79, 2101-2114, 1998.

Ricchiazzi, P., O'Hirok, W., and Gautier, C.: The effect of NONLambertian Surface Reflectance on Aerosol Radiative Forcing, Fifteenth ARM Science Team Meeting Proceedings, Daytona Beach, Florida, USA, 14-18 March, 2005.

Rodríguez, S., Van Dingenen, R., Putaud, J.-P., Dell'Acqua, A., Pey, J., Querol, X., Alastuey, A., Chenery, S., Ho, K.-F., Harrison, R., Tardivo, R., Scarnato, B., and Gemelli, V.: A study on the relationship between mass concentrations, chemistry and number size distribution of urban fine aerosols in Milan, Barcelona and London, Atmos. Chem. Phys., 7, 2217-2232, 2007 , http://www.atmos-chem-phys.net/7/2217/2007/. 
Rodríguez, S., Querol, X., Alastuey, A., and de la Rosa, J.: Atmospheric particulate matter and air quality in the Mediterranean: A review, Environ. Chem. Lett., 5, 1-7, 2007.

Roger, J. C., Mallet, M., Dubuisson, P., Cachier, H., Vermote, E., Dubovik, O., and Despiau, S.: A synergetic approach for estimating the local direct aerosol forcing: Application to an urban zone during the Expérience sur Site pour Contraindre les Modèles de Pollution et de Transport d'Emission (ESCOMPTE) experiment, J. Geophys. Res., 111, D13208, doi:10.1029/2005JD006361, 2006.

Rosenfeld, D.: Suppression of rain and snow by urban and industrial air pollution, Science, 287, 1793-1796, 2000.

Rossow, W. B. and Schiffer, R. A.: Advances in understanding clouds from ISCCP, B. Am. Meteorol. Soc., 80, 2261-2287, 1999.

Russel, P. B., Livingstone, J. M., Hignett, P., Kinne, S., Wong, J., Chien, A., Bergstrom, R., Durkee, P., and Hobbs, P. V.: Aerosolinduced radiative flux changes off the United States mid-Atlantic coast: Comparison of values calculated from sunphotometer and in situ data with those measured by airborne pyranometer, J. Geophys. Res., 104, 2289-2307, 1999.

Salomonson, V. V., Barnes, W. L., Maymon, P. W., Montgomery, H. E., and Ostrow, H.: MODIS: Advanced facility instrument for studies of the Earth as a system, IEEE T. Geosci. Remote, 27, 145-152, 1989.

Satheesh, S. K. and Ramanathan, V.: Large differences in tropical aerosol forcing at the top of the atmosphere and Earth's surface, Nature, 405, 60-63, 2000.

Schaaf, C. B., Gao, F., Strahler, A. H., Lucht, W., Li, X., Tsang, T., Strugnell, N. C., Zhang, X., Jin, Y., Muller, J.-P., Lewis, P., Barnsley, M., Hobson, P., Disney, M., Roberts, G., Dunderdale, M., Doll, C., d'Entremont, R. P., Hu, B., Liang, S., Privette, J. L., and Roy, D.: First operational BRDF, albedo nadir reflectance products from MODIS, Remote Sens. Environ., 83, 135-148, 2002.

Sheridan, P. J. and Ogren, J. A.: Observations of the vertical and regional variability of aerosol optical properties over central and eastern North America, J. Geophys. Res., 104, 16793-16805, 1999.

Smirnov, A., Holben, B. N., Eck, T. F., Dubovik, O., and Slutsker, I.: Cloud-screening and quality control algorithms for the AERONET database, Remote Sens. Environ., 73, 337-349, 2000.

Smirnov, A., Holben, B. N., Eck, T. F., Slutsker, I., Chatenet, B., and Pinker, R. T.: Diurnal variability of aerosol optical depth observed at AERONET (Aerosol Robotic Network) sites, Geophys. Res. Lett., 29, 2115, doi:10.1029/2002GL016305, 2002.

Sogacheva, L., Hamed, A., Facchini, M. C., Kulmala, M., and Laaksonen, A.: Relation of air mass history to nucleation events in Po Valley, Italy, using back trajectories analysis, Atmos Chem. Phys., 7, 839-853, 2007.
Stamnes, K., Tsay, S. C., Wiscombe, W., and Jayaweera, K.: Numerically stable algorithm for discrete-ordinate-method radiative transfer in multiple scattering and emitting layered media, Appl. Optics, 27, 2502-2509, 1998.

Stern, D. I.: Reversal of the trend in global anthropogenic sulfur emissions, Global Environ. Chang., 16, 207-220, 2006.

Sumanth, E., Mallikarjuna, K., Stephen, J., Moole, M., Vinoj, V., Satheesh, S. K., and Krishna Moorthy, K.: Measurements of aerosol optical depth and black carbon over Bay of Bengal during post-monsoon season, Geophys. Res. Lett., 31, L16115, doi:10.1029/2004GL020681, 2004.

Van Dingenen, R., Raes, F., Putaud, J.-P., Baltensperger, U., Charron, A., Facchini, M.-C., Decesari, S., Fuzzi, S., Gehrig, R., Hansson, H.-C., Harrison, R. M., Hüglin, C., Jones, A. M., Laj, P., Lorbeer, G., Maenhaut, W., Palmgren, F., Querol, X., Rodriguez, S., Schneider, J., Ten Brink, H., Tunved, P., Tørseth, K., Wehner, B., Weingartner, E., Wiedensohler, A., and Wåhlin, P.: A European aerosol phenomenology. 1. Physical characteristics of particulate matter at kerbside, urban, rural and background sites in Europe, Atmos. Environ., 38, 2561-2577, 2004.

Wendling, P., Stifter, A., Mayer, B., Fiebig, M., Kiemle, C., Flentje, H., Wendisch, M., Armbruster, W., Leiterer, U., von HoyningenHuene, W., and Petzold, A.: Aerosol-radiation interaction in the cloudless atmosphere during LACE 98. 2. Aerosol-induced solar irradiance changes determined from airborne pyranometer measurements and calculations, J. Geophys. Res., 107, 8131, doi:10.1029/2000JD000288, 2002.

Yu, H., Dickinson, R. E., Chin, M., Kaufman, Y. J., Zhou, M., Zhou, L., Tian, Y., Dubovic, O., and Holben, B. N.: Direct radiative effect of aerosols as determined from a combination of MODIS retrievals and GOCART simulations, J. Geophys. Res., 109, D03206, doi:10.1029/2003JD003914, 2004.

Yu, H., Kaufman, Y. J., Chin, M., Feingold, G., Remer, L. A., Anderson, T. L., Balkanski, Y., Bellouin, N., Bouche, O., Christopher, S., DeCola, P., Kahn, D., Loeb, N., Reddy, M. S., Schulz, M., Takemura, T., and Zhou, M.: A review of measurementbased assessments of the aerosol direct radiative effect and forcing, Atmos. Chem. Phys., 6, 613-666, 2006,

http://www.atmos-chem-phys.net/6/613/2006/.

Zhou, M., Yu, H., Dickinson, R. E., Dubovik, O., and Holben, B. N.: A normalized description of the direct effect of key aerosol types on solar radiation as estimated from Aerosol Robotic Network aerosols and Moderate Resolution Imaging Spectroradiometer albedos, J. Geophys. Res., 110, D19202, doi:10.1029/2005JD005909, 2005. 